\title{
Taxonomic revision of the Rineloricaria species (Siluriformes: Loricariidae) from the Paraguay River basin
}

\author{
Héctor S. Vera-Alcaraz ${ }^{1}$, Carla S. Pavanelli², 3 and Cláudio H. Zawadzki ${ }^{3}$
}

Species of the genus Rineloricaria from the Paraguay River basin were revised, the following species and geographic distributional patterns were found: R. aurata, Paraguay River basin in Brazil and Paraguay, rio Guaporé in Brazil; R. cacerensis, Paraguay River near Cáceres in Brazil; R. lanceolata, Paraguay River basin in Brazil and Paraguay, Guaporé, Ji-Paraná, Purus, Solimões, and Araguaia rivers in Brazil, Marañón and Madre de Dios rivers in Peru; R. parva, Paraguay River basin in Brazil and Paraguay, Paraná River in Argentina, Uruguay River in Brazil. Loricaria hoehnei is proposed as a new junior synonym of $R$. lanceolata. A key to the species of Rineloricaria from the Paraguay River basin is provided.

As espécies do gênero Rineloricaria da bacia do rio Paraguai foram revisadas, as seguintes espécies e padrões de distribuição foram encontradas: $R$. aurata, bacia do rio Paraguai no Brasil e Paraguai, rio Guaporé no Brasil; $R$. cacerensis, rio Paraguai perto de Cáceres no Brasil; R. lanceolata, bacia do rio Paraguai no Brasil e Paraguai, rios Guaporé, Ji-Paraná, Purus, Solimões e Araguaia no Brasil, rios Marañón e Madre de Dios no Peru; R. parva, bacia do rio Paraguai no Brasil e Paraguai, rio Paraná na Argentina, rio Uruguai no Brasil. Loricaria hoehnei é proposta como novo sinônimo júnior de R. lanceolata. Uma chave de identificação para as espécies de Rineloricaria da bacia do rio Paraguai é fornecida.

Key words: Loricariinae, Neotropical fishes, Suckermouth armored catfishes.

\section{Introduction}

The genus Rineloricaria Bleeker, 1862 actually comprises 65 valid species (Ferraris, 2007; Fichberg \& Chamon, 2008; Ghazzi, 2008; Ingenito et al., 2008; Rapp Py-Daniel \& Fichberg, 2008; Rodriguez \& Miquelarena, 2008; Rodriguez \& Reis, 2008). Species of this genus exhibit an extensive variation in their body sizes, color pattern, arrangement of abdominal plates, shape of the head, form, and placement of their sexually dimorphic odontodes. Species are found from Panama to central Argentina, including the Chico River in Panama; Atrato, Magdalena, Patía, and Sinú rivers in Colombia; Esmeraldas and Mira rivers in Ecuador; the Atlantic coastal river drainages from northeastern Brazil to the south of Uruguay; and the major tropical rivers of South America, the Orinoco, Amazonas, and La Plata basins. Fichberg \& Chamon (2008) diagnosed the genus by the combination of the following characters: postorbital notch present; inferior lip with short rounded papillae; premaxilla with 7 to 15 teeth on each hemiseries; dentary teeth strong, deeply bicuspidate, and larger than premaxillary; coloration of dorsal region with dark-brown bars or blotches; abdomen with a conspicuous polygonal preanal plate, usually bordered by other three large trapezoidal plates. In addition, these authors mentioned as useful some of the following features associated with the sexual dimorphism of mature males: numerous hypertrophied odontodes along the sides of the head and the dorsal surface of pectoral fin in some species (generally thick, short, and curved odontodes); and well-developed odontodes over all of the predorsal area (generally thin, long, and erected or depressed odontodes), sides of head and dorsum of pectoral fin in other members of the genus.

Taxonomy of the group was established for a long time considering only Rineloricaria (type species: Loricaria lima Kner, 1853) as valid (Isbrücker \& Nijssen, 1976; Isbrücker, 1978). However, Isbrücker et al. (2001) split Rineloricaria in four genera according to external characters as caudal fin filaments, widthness of body, abdominal plate arrangements, form and distribution of sexually dimorphic odontodes. These authors validated Hemiloricaria (type species: Hemiloricaria

${ }^{1}$ Pontifícia Universidade Católica do Rio Grande do Sul (PUCRS), Programa de Pós-Graduação em Zoologia, Faculdade de Biociências, Av. Ipiranga, 6681, 90619-900 Porto Alegre, RS, Brazil. Bolsista CAPES, PEC-PG Paraguay-Brasil. hsveraalcaraz@gmail.com

${ }^{2}$ Universidade Estadual de Maringá (UEM), Programa de Pós-Graduação em Ecologia de Ambientes Aquáticos Continentais (PEA), Av. Colombo 5790, 87020-900 Maringá, PR, Brazil. carlasp@nupelia.uem.br

${ }^{3}$ Universidade Estadual de Maringá (UEM), Centro de Ciências Biológicas, Núcleo de Pesquisas em Limnologia, Ictiologia e Aquicultura (Nupélia), Av. Colombo 5790, 87020-900 Maringá, PR, Brazil. chzawadzki@hotmail.com 
caracasensis Bleeker, 1862) from the Rineloricaria synonymy, and proposed as new genera Fonchiiichthys Isbrücker \& Michels (type species: Loricaria uracantha Kner, 1863) and Leliella Isbrücker (type species: Rineloricaria heteroptera Isbrücker \& Nijssen, 1976). This arrangement was partially accepted by some authors (Ferraris, 2007; Rodriguez \& Reis, 2008; Rodriguez \& Miquelarena, 2008; Ingenito et al., 2008) and rejected by others (Ferraris, 2003; Covain \& Fisch-Muller, 2007; Rapp Py-Daniel \& Fichberg, 2008; Fichberg \& Chamon, 2008). There is not a consensus whether to accept or not the splitting of Rineloricaria in more groups, in consequence we decided to use the arrangement summarized in Ferraris (2003) until a classification based on cladistic approaches be formally published for this group. For a summary of the debate on Hemiloricaria and Rineloricaria see Fichberg \& Chamon (2008) and Ingenito et al. (2008).

We have revised the following Rineloricaria species: $R$. aurata, $R$. cacerensis, $R$. hoehnei, and $R$. parva. These species were originally described from the Paraguay River basin and are commonly found from large rivers to small streams throughout this basin, but identities of most of them are problematic considering that they are basically known from their original descriptions, which are at best incomplete. In this paper we contribute to this issue providing new diagnosis, expanding descriptions, and presenting an identification key for the Rineloricaria species described from the Paraguay River basin.

\section{Material and Methods}

Counts and measurements were made on the left side of specimens using digital caliper to the nearest $0.1 \mathrm{~mm}$. Methodology follows Isbrücker \& Nijssen (1978) excepting postdorsal- and postanal-fin lengths, see below. Measurements of fin spines and counts of thoracic and lateral scutes are according to Isbrücker \& Nijssen (1978) but we modified nomenclature as unbranched-fin ray, lateral abdominal plates, and longitudinal lateral plates. The following measurements and counts were added: free maxillary barbel (from its base at lower lip border to its distal tip); prepectoral-, prepelvic-, and preanal-fin lengths (from snout tip to the origin of the anteriormost unbranched-fin ray); postdorsal-, postpectoral-, postpelvic-, and postanal-fin lengths (from origin of anteriormost unbranched-fin ray to base of middle triangular caudal plate); eye diameter (horizontal measurement of eye between its margins, excluding orbital notch); internarial width (distance between nostrils); and posterior plates of the median series (longitudinal plates in the caudal peduncle bearing the sensory canal between two very proximate keels, first counted plate is posterior to the last plate of the mid-ventral series, last counted one is the triangular plate of the caudal fin). Measurements and abdominal plates are shown on Figure 1.

Nomenclature of plates and bones of the head, and of the lateral plate series follows Schaefer (1997). Nomenclature of parieto-supraoccipital follows Arratia \& Gayet (1995) and of compound pterotic follows Aquino \& Schaefer (2002).
Nomenclature of posterior, median, and anterior abdominal plate complex follows Isbrücker \& Nijssen (1979) and are shown on Figure 1. The posterior complex consists of a welldefined preanal plate preceded by three larger polygonal plates, these plates are bordered by five or six small polygonal plates curved in a transversal series that reaches the last lateral abdominal plate. The median complex consists of middle-sized polygonal plates situated between lateral abdominal plates. The anterior complex consists of small polygonal plates situated on the pectoral girdle.

In the species descriptions the values in parentheses indicate the number of specimens with a particular count. In the description of $R$. cacerensis the numbers indicated by an asterisk are counts of the lectotype. Cleared and stained specimens (c\&s) according to Taylor \& van Dyke (1985) procedures were used for osteological observations and counts of plates, branchiostegal rays, vertebrae, and ribs. Sexes were characterized after dissecting specimens, or according to the presence of hypertrophied odontodes developed on sides and dorsum of the head, predorsal plates, and dorsum of the pectoral fin of breeding male specimens.

Principal Component Analysis (PCA) was performed using the software PAST (Hammer et al., 2001) in order to detect differences between populations of Rineloricaria lanceolata and $R$. hoehnei; and differences between $R$. aurata, $R$. cacerensis, $R$. lanceolata, and $R$. parva. The specimens used in this analysis are indicated in parentheses in the examined material. Samples of $R$. lanceolata from the upper Amazonas River basin in Perú includes the Huallaga, Urubamba, and Ucayali rivers, samples from the middle Amazonas River and tributaries includes the Solimões, Purus, Madre de Dios, and Guaporé rivers. PCA was performed on the co-variance matrices of log transformed data of the 31 measurements described above; the superior and inferior caudal-fin rays measurements were excluded of the analysis because of having many absent data due damaged specimens.

Institutional acronyms are as listed by Leviton et al. (1985), with the addition of CPUFMT (Coleção de Peixes da Universidade Federal de Mato Grosso, Brazil), CZCEN (Colección Zoológica de la Facultad de Ciencias Exactas y Naturales, Universidad Nacional de Asunción, Paraguay), DZSJRP (Departamento de Zoologia e Botânica, Universidade Estadual Paulista Júlio de Mesquita Filho, Câmpus de São Jose do Rio Preto, Brazil), MZUEL (Museu de Zoologia, Universidade Estadual de Londrina, Brazil), NUP (Coleção Ictiológica do Núcleo de Pesquisas em Limnologia, Ictiologia e Aquicultura, Universidade Estadual de Maringá, Brazil), UMSS (Universidad Mayor de San Simón, Bolivia), ZUFMS-PIS (Coleção Zoológica de Referência da Universidade Federal de Mato Grosso do Sul, Brazil). Data of examined and comparative material are given with the species listed alphabetically, type specimens are listed first, and the non-type specimens are ordered as follows (bold format provided only in examined material): Country; Departamento, Estado, or Provincia; collection acronym and catalog number; number of specimens; number of specimens used for morphomeristic analyses in 
$\mathrm{TL}$
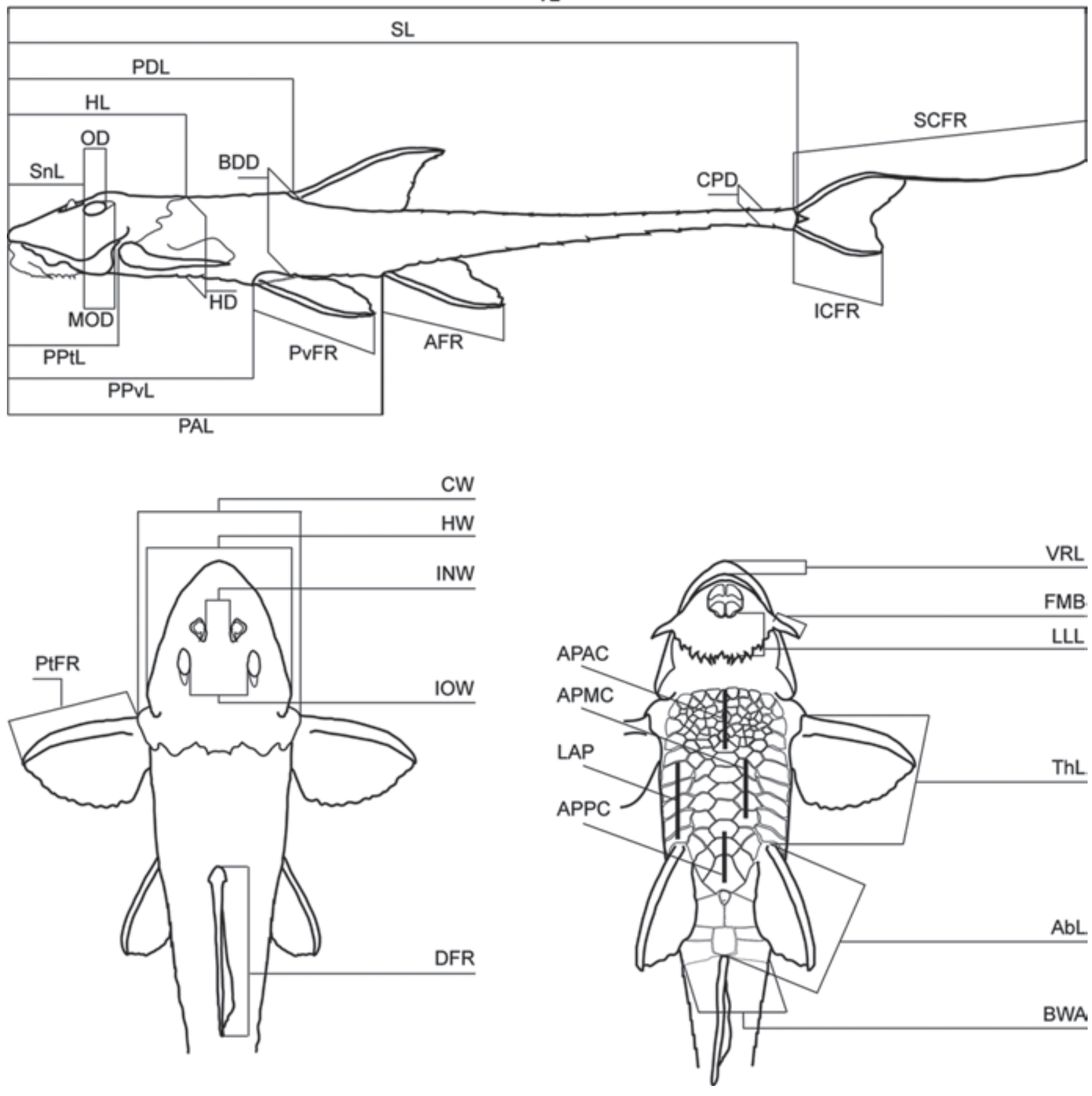

Fig. 1. Measurements used in this study (shown on a generalized Rineloricaria) based on Isbrücker \& Nijssen (1978) with some modifications; see Material and Methods for explanations. The abbreviations used are listed alphabetically: AbL: Abdominal length, AFR: Anal-fin ray, APAC: Abdominal plates of the anterior complex, APMC: Abdominal plates of the median complex, APPC: Abdominal plates of the posterior complex, BDD: Body depth at dorsal fin, BWA: Body width at anal fin, CPD: Caudal peduncle depth, CW: Cleithral width, DFR: Dorsal-fin ray, FMB: Free maxillary barbel, HD: Head depth, HL: Head length, HW: Head width, ICFR: Inferior caudal-fin ray, INW: Internarial width, IOW: Interorbital width, LAP: Lateral abdominal plates, LLL: Lower lip length, MOD: Maximum orbital diameter, OD: Orbital diameter, PAL: Preanal length, PDL: Predorsal length, PPtL: Prepectoral length, PPvL: Prepelvic length, PtFR: Pectoral-fin ray, PvFR: Pelvic-fin ray, SCFR: Superior caudal-fin ray, SL: Standard length, SnL: Snout length, ThL: Thoracic length, TL: Total length, VRL: Ventrorostral length. 
parentheses (provided only for those lots used in measurements, counts, and PCA); size range of specimens examined; and the collecting locality. We indicate if type material was analyzed based on photographs. Type images were downloaded from Museums webpages, or consulting the All Catfish Species Inventory Image Base (Morris et al., 2006).

\section{Results}

Principal Component Analysis. Results of the PCA performed with the Rineloricaria hoehnei and $R$. lanceolata data are shown on Figure 2a and Table 1. The first component has $80.8 \%$ of variance and the eigenvectors were all positive; this is interpreted as a general size factor according to Jolicoeur \& Mosimann (1960) and graphs including the PC1 axis are not shown. The variance of the second and third components was $4.8 \%$ and $3.5 \%$, respectively, and this was interpreted as a variation in the body form following Bookstein (1989). Plots of factor scores for both PC2 and PC3 axes show specimens grouped in a broadly overlapping pattern. The loading variables that contributed most heavily for these axes are highlighted in bold in Table 1. Specimens of $R$. lanceolata were grouped into

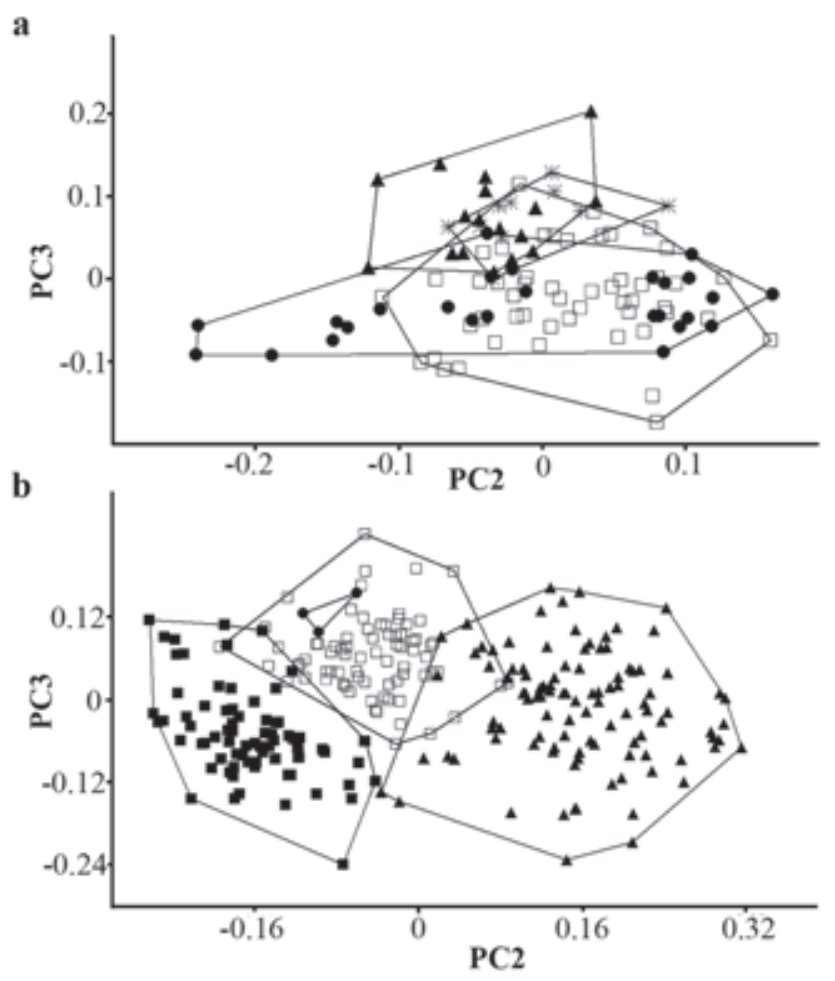

Fig. 2. Plots of scores obtained by Principal Components Analysis. a) Three populations of Rineloricaria lanceolata (Triangles $=$ Upper Amazonas River, Asterisks = Araguaia River, Dots $=$ Middle Amazonas River and tributaries) and one population of Rineloricaria hoehnei (Squares = Paraguay River basin). b) Rineloricaria aurata (Squares), Rineloricaria cacerensis (Dots), Rineloricaria lanceolata (Triangles), and Rineloricaria parva (Filled squares). three datasets in order to represent populations from the type locality (upper Amazonas in Peru), middle Amazonas River, and Araguaia River. Last two populations encompass the geographical distribution stated for this species by Isbrücker (1973). Plots of the R. hoehnei dataset (Paraguay River basin) overlap the $R$. lanceolata dataset, especially those from the Guaporé, Purus, and Araguaia rivers. This analysis suggests homogeneous morphology between both species and supports the synonymy of $R$. hoehnei under $R$. lanceolata, which is discussed in the description of the latter. Range of variation of the morphometric data in Table 4 also shows overlapping values. PCA performed with the $R$. aurata, $R$. cacerensis, $R$. lanceolata (including Paraguay River specimens), and $R$. parva data are shown on Figure $2 \mathrm{~b}$. Variance of the first, second, and third components are $80.8 \%, 8.8 \%$, and $2.8 \%$, respectively. Plots of factor scores for both PC2 and PC3 axes show species grouped independently, excepting for $R$. cacerensis which fall inside set of $R$. aurata, no ovelapping boundaries among the $R$. cacerensis, $R$. lanceolata, and $R$. parva samples, and a small overlapping pattern of $R$. aurata with boundaries of $R$. lanceolata and $R$. parva. The loading variables that contributed most heavily for these axes are highlighted in bold in Table 1 . This analysis suggests morphometric differences between species, especially on axis 2 where $R$. lanceolata is distinguished from $R$. parva and $R$. cacerensis.

\section{Rineloricaria aurata (Knaack, 2003) Figs. 3, 4a, 5, 6}

Hemiloricaria aurata Knaack, 2003: 58 [original description; holotype: ZMA 123591; pictures of the holotype alive and conserved; type-locality: río Aquidabán at Paso Barreto, Concepción, Departamento de Concepción, Paraguay]. Ferraris, 2007: 245 [listed; Paraguay].

Rineloricaria. -Knaack, 2003: 57 [picture of a specimen from the Aquidabán River in Paraguay; comparison with Hemiloricaria aurata].

Hemiloricaria cacerensis non Miranda Ribeiro, 1912. Carvalho \& Albert, 2011: 195 [Guaporé River].

Diagnosis. Rineloricaria aurata is distinguished from most of its congeners by having four lateral plate series in longitudinal rows below the dorsal fin, the mid-dorsal series absent (Fig. 4a) [vs. five lateral plate series in longitudinal rows below the dorsal fin, the mid-dorsal series present and consisting in two to ten keeled plates situated below the dorsal series and beginning around insertion of the first dorsal-fin ray (Fig. 4b and 4c) in $R$. aequalicuspis, $R$. altipinnis, $R$. anhanguapitan, $R$. anitae, $R$. baliola, $R$. cacerensis, $R$. capitonia, $R$. caracasensis, $R$. daraha, $R$. eigenmanni, $R$. fallax, $R$. formosa, $R$. hasemani, $R$. heteroptera, $R$. isaaci, $R$. jaraguensis, $R$. jubata, $R$. konopickyi, $R$. kronei, $R$. latirostris, $R$. maacki, R. malabarbai, R. maquinensis, $R$. melini, $R$. microlepidogaster, $R$. morrowi, $R$. osvaldoi, $R$. pentamaculata, $R$. phoxocephala, $R$. platyura, $R$. reisi, $R$. rupestris, $R$. steindachneri, $R$. stewarti, $R$. teffeana, $R$. 
Table 1. Variable loadings for the Principal Component Analysis, the modular higher eigenvectors of Principal Component axes 2 and 3 are shown in bold.

\begin{tabular}{|c|c|c|c|c|c|c|}
\hline \multirow{2}{*}{$\begin{array}{ll} & \text { Species } \\
\text { Variables } & \\
\end{array}$} & \multicolumn{3}{|c|}{$\begin{array}{l}\text { R. lanceolata } \\
\text { and R. hoehnei }\end{array}$} & \multicolumn{3}{|c|}{$\begin{array}{c}\text { R.aurata, } R \text {. cacerensis, } \\
\text { R. lanceolata, and } R \text {. parva }\end{array}$} \\
\hline & Axis 1 & Axis 2 & Axis 3 & Axis 1 & Axis 2 & Axis 3 \\
\hline Standard length & 0.164 & -0.074 & 0.114 & 0.151 & -0.093 & 0.041 \\
\hline Head length & 0.188 & 0.099 & -0.010 & 0.167 & 0.050 & 0.118 \\
\hline Predorsal length & 0.199 & 0.083 & 0.002 & 0.170 & 0.047 & 0.153 \\
\hline Postdorsal length & 0.146 & -0.154 & 0.162 & 0.140 & -0.150 & -0.004 \\
\hline Prepectoral length & 0.187 & 0.108 & -0.029 & 0.170 & 0.036 & 0.094 \\
\hline Postpectoral length & 0.160 & -0.118 & 0.140 & 0.147 & -0.116 & 0.037 \\
\hline Prepelvic length & 0.208 & 0.096 & 0.021 & 0.185 & 0.031 & 0.124 \\
\hline Pospelvic length & 0.150 & -0.156 & 0.143 & 0.138 & -0.144 & 0.023 \\
\hline Preanal length & 0.212 & 0.045 & 0.044 & 0.181 & 0.014 & 0.136 \\
\hline Posanal length & 0.134 & -0.195 & 0.178 & 0.127 & -0.181 & -0.017 \\
\hline Unbranched dorsal-fin ray & 0.142 & -0.291 & 0.114 & 0.204 & -0.138 & -0.358 \\
\hline Unbranched pectoral-fin ray & 0.121 & -0.205 & -0.057 & 0.188 & -0.103 & -0.310 \\
\hline Unbranched pelvic-fin ray & 0.150 & -0.186 & 0.009 & 0.200 & -0.040 & -0.265 \\
\hline Unbranched anal-fin ray & 0.141 & -0.241 & 0.007 & 0.200 & 0.008 & -0.258 \\
\hline Thoracic length & 0.236 & 0.068 & 0.018 & 0.197 & 0.012 & 0.194 \\
\hline Abdominal length & 0.194 & 0.014 & 0.044 & 0.170 & -0.005 & 0.144 \\
\hline Cleithral width & 0.180 & 0.055 & 0.050 & 0.175 & 0.057 & 0.103 \\
\hline Depth at dorsal-fin origin & 0.232 & 0.003 & 0.020 & 0.229 & 0.032 & 0.045 \\
\hline Width at anal-fin origin & 0.238 & 0.061 & 0.055 & 0.229 & 0.079 & 0.076 \\
\hline Caudal peduncle depth & 0.204 & 0.176 & 0.084 & 0.184 & 0.174 & 0.284 \\
\hline Caudal peduncle width & 0.221 & 0.152 & -0.101 & 0.256 & 0.106 & -0.054 \\
\hline Snout length & 0.192 & 0.161 & -0.072 & 0.192 & 0.112 & 0.025 \\
\hline Eye diameter & 0.118 & -0.080 & 0.091 & 0.134 & -0.180 & -0.060 \\
\hline Maximum orbital diameter & 0.126 & -0.224 & 0.060 & 0.116 & -0.307 & 0.018 \\
\hline Interorbital width & 0.174 & 0.079 & 0.075 & 0.208 & 0.083 & -0.091 \\
\hline Internarial width & 0.165 & 0.268 & 0.088 & 0.185 & 0.128 & 0.096 \\
\hline Head depth & 0.208 & 0.061 & 0.001 & 0.191 & 0.076 & 0.129 \\
\hline Head width & 0.174 & 0.032 & 0.029 & 0.174 & 0.052 & 0.111 \\
\hline Free maxillary barbel & 0.155 & -0.471 & -0.724 & 0.168 & -0.253 & -0.426 \\
\hline Ventrorostral length & 0.208 & -0.108 & -0.059 & 0.066 & -0.652 & 0.381 \\
\hline Lower lip length & 0.141 & 0.413 & -0.535 & 0.210 & 0.389 & -0.129 \\
\hline
\end{tabular}

tropeira, and $R$. zaina]; and by presenting breeding male specimens with sexually dimorphic odontodes on the dorsum of the head and predorsal region (Fig. 3) [vs. sexually dimorphic odontodes absent on dorsum of the head and predorsal region (Fig. 12) in R. cadeae, R. castroi, R. catamarcensis, R. langei, $R$. lima, $R$. longicauda, $R$. misionera, $R$. nigricauda, $R$. pareiacantha, R. parva, R. quadrensis, $R$. sanga, $R$. setepovos, $R$. stellata, $R$. strigilata, $R$. uracantha, and $R$. wolfei]. It is distinguished from remaining members of the genus by having the dorsum of the head rough, with pronounced ridges from nasal plates to the frontal bones [vs. dorsum of the head smooth, without ridges between nostrils and interorbital region in $R$. beni, R. felipponei, R. lanceolata, $R$. magdalenae, $R$. sneiderni, and $R$. thrissoceps].

Description. Morphometric data presented in Table 2. Snout tip straight in lateral view, not raised. Dorsal profile from snout tip to posterior nasal plates straight, convex from frontals to nuchal plate, straight from predorsal plates to base of unbranched dorsal-fin ray, declined at dorsal-fin base, straight from end of dorsal-fin base to penultimate dorsal plate, elevated from last dorsal plate to end of caudal fin. Ventral profile from snout tip to anal-fin base convex, straight from that point to penultimate ventral plate, declined from last ventral plate to end of caudal fin.
Snout tip pointed in dorsal view, lateral margins of head straight. Odontodes of head and trunk small, thick, aligned. Dorsum of head rough; pronounced ridges between nostrils on posterior nasal plates to anterior margin of frontals, posterior to eyes on parieto-supraoccipital and compound pterotic; moderate ridges on anterior nasal plates, frontals, sphenotic, and compound pterotic. Infraorbital series with six bones, infraorbital 1 with a sensorial pore exposed ventrally, infraorbitals 2, 3, and 4 convexly raised from anterior portion of snout to eye. Rostral plate with an area without odontodes at tip of snout, narrow, horizontally elongated, short, not surpassing sensorial pore ventrally exposed of infraorbital 1 . Posterior margin of parieto-supraoccipital slightly concave to straight, lateral margins truncate. Predorsal plates and first three lateral plates of dorsal series with pronounced ridges or keels. Superior margin of orbit raised, postorbital notch large. Eye large, rounded to slightly oval horizontally.

Lower lip narrow, ventral surface covered by short papillae with rounded tip, papillae slightly bigger at line bordering upper lip and close to dentary. Lower lip margin with mediumlengthed fringes; upper lip margin with short fringes. Maxillary barbel long, surpassing distal border of lower lip. Teeth bicuspid, long, mesial cusp greater and wider than lateral, dentary teeth larger than premaxillary. Premaxilla with 6(11), 7(27), 8(4), or 9(1) teeth; dentary with 6(11), 7(36), 8(11), or 


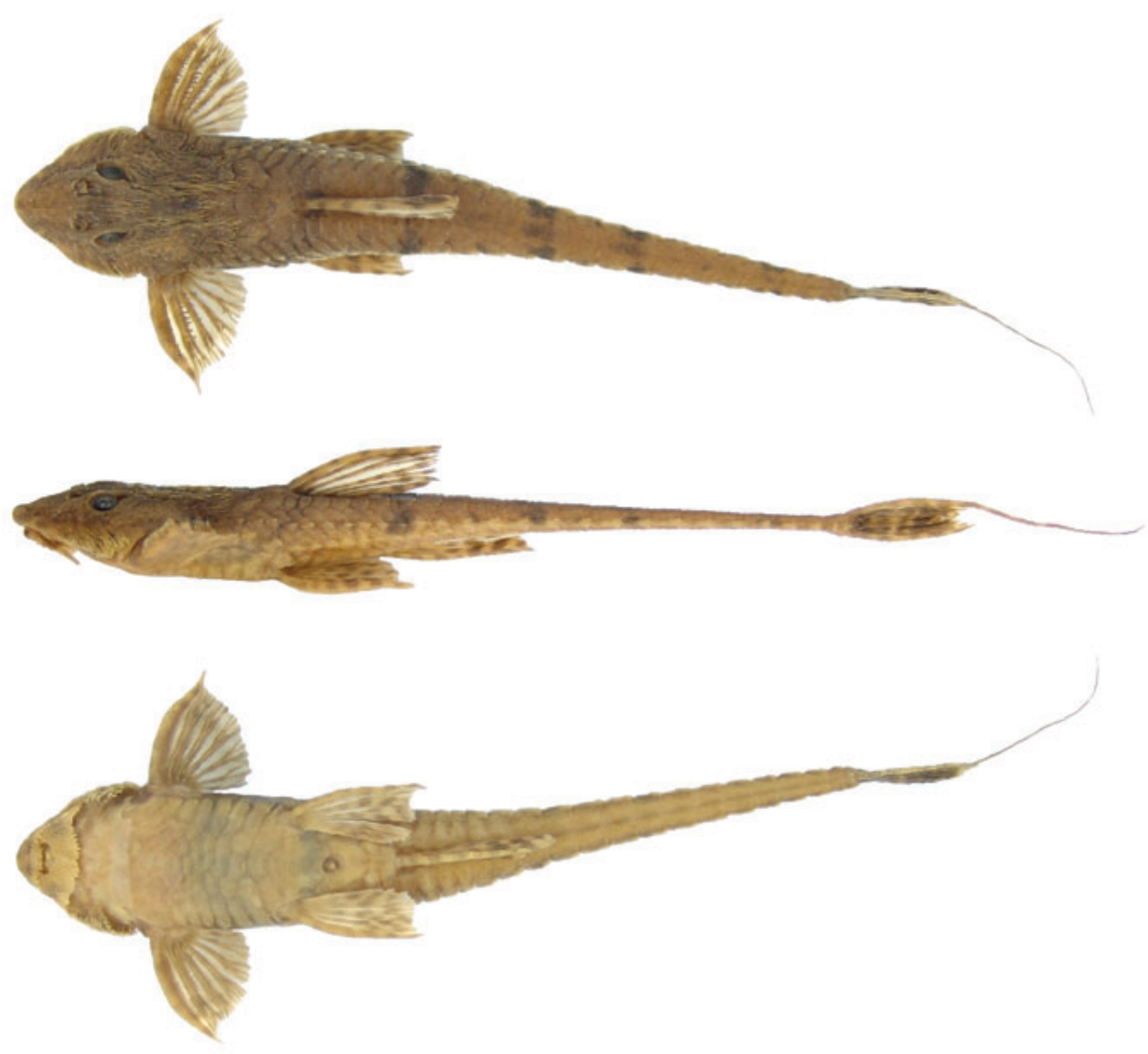

Fig. 3. Rineloricaria aurata, NUP 3440, male, 74.1 mm SL, córrego Cancela, affluent of the rio Cuiabá, Paraguay River basin, Nobres, Mato Grosso State, Brazil.

9(2) teeth. Sexual dimorphism on teeth present (see sexual dimorphism). Branchiostegal rays 4(8).

Body narrow and short, four lateral plate series in longitudinal rows below dorsal fin: dorsal, median, mid-ventral, and ventral; mid-dorsal series absent (Fig. 4a). Median and mid-ventral series with rough well-developed keels; last plate of mid-ventral series extended around end of anal fin. Median series bearing sensory canal between two proximate keels on caudal peduncle. Longitudinal lateral plates 29(2), 30(12), 31(40), 32(19), or 33(2); posterior plates of median series 13(1), 15(12), 16(47), or 17(15). Lateral line complete. Lateral abdominal plates 4(2), 5(22), 6(45), or 7(6); borders of plates not in contact with lateral plates of mid-ventral series. Lateral region of body posterior to pectoral-fin insertion with a broad area of naked skin between borders of lateral plates of mid-ventral series and of lateral abdominal plates, thickness similar to caudal peduncle width (Fig. 4a). Abdominal plates of posterior complex with a large well-defined preanal plate bordered by three plates and these by five plates. Abdominal plates of median complex parallel and longitudinally arranged in three series posteriorly and in four series anteriorly. Abdominal plates of anterior complex irregular, smaller anteriorly, not projected toward lip; anterior margin convex, reaching horizontal line of anterior margin of cleithrum exposed ventrally. Vertebrae 26(1), 27(8), or 28(2); ribs 4(9) or 5(4).

Dorsal fin ii,7(68), dorsal-fin spinelet present, locking mechanism not functional; depressed unbranched ray reaching fourth to fifth plate posterior to its base, depressed 


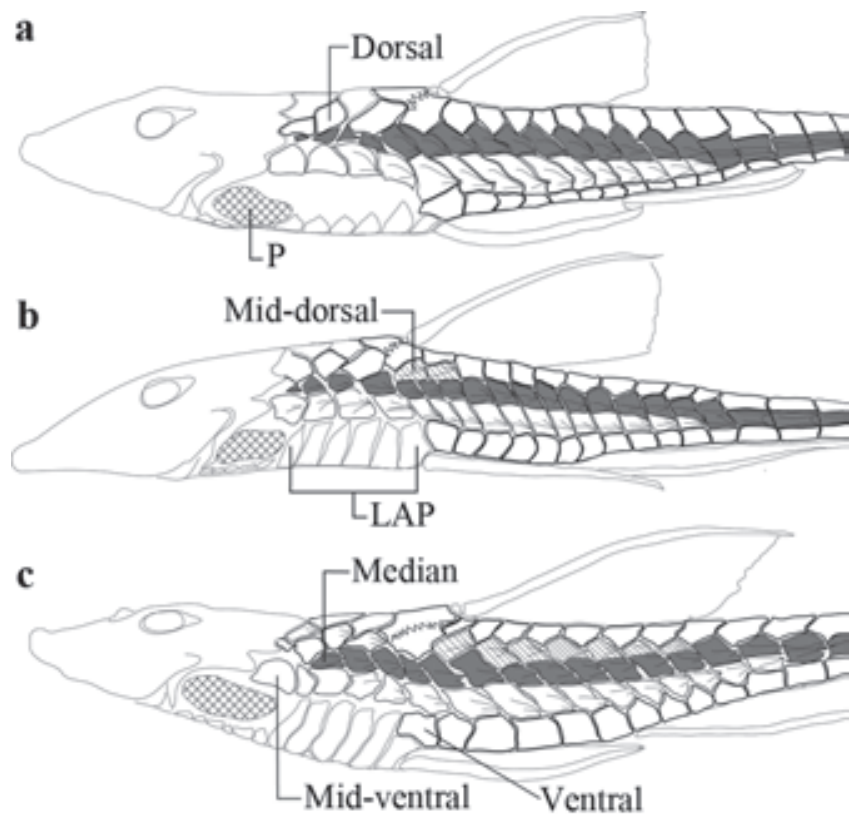

Fig. 4. Lateral plate series in three Rineloricaria species: a) $R$. aurata, b) $R$. eigenmanni, c) $R$. hasemani. See also the region posterior to the pectoral-fin insertion, which shows a broad area of naked skin in the Fig. 4a, and a slender area in Figs. 4b and 4c. P = Pectoral-fin insertion, LAP = Lateral abdominal plates.

last branched ray reaching third or fourth plate; dorsal-fin base with 3(1) or 4(76) plates; distal margin truncate. Pectoral fin i,6(69), depressed unbranched ray slightly surpassing pelvic-fin origin, distal margin truncate. Pelvic fin i,5(71), depressed unbranched ray slightly surpassing anal-fin origin, distal margin truncate. Anal fin i,5(69), depressed unbranched ray reaching sixth plate posterior to its base, depressed last branched ray reaching fourth to fifth plate; anal-fin base with two plates; distal margin truncate. Caudal fin emarginated, $\mathrm{i}, 9, \mathrm{i}(3)$ or i,10,i(63), superior unbranched ray extended as long filament similar in length to half SL.

Color in alcohol. Dorsal surface of body with light or dark brown ground coloration; ventral surface yellow or light brown, ventral plates posterior to pelvic fin with dark brown longitudinal spots forming stripes. Dorsal surface of head from anterior margin of snout to eyes with two longitudinal dark brown stripes. Lateral margins of head with irregular dark brown dots. Posterior region of parieto-supraoccipital with dark brown spot. Pores of sensorial canal of head and lateral line highlighted by black pigments. Dorsal surface of upper lip with two longitudinal light brown stripes, dorsal surface of lower lip with transverse light brown stripe. Dorsal surface of trunk with six narrow, transverse dark brown bands; first at dorsal-fin origin, oblique, extending toward last pectoral-fin ray; second just behind dorsal-fin base, broad, conspicuous; following bands similar, equidistantly separated and sometimes incomplete. Immature specimens about $30 \mathrm{~mm}$ SL with pectoral, pelvic, dorsal, and anal fins light brown with dark brown spot on base of first rays, another spot on distal portions of first rays not reaching fin margin, distal spot extending to last ray forming transversal stripe; caudal fin almost totally dark brown except for a light brown blotch on anterior half of four median rays. Specimens about $45 \mathrm{~mm}$ SL with pectoral, pelvic, dorsal, and anal fins light brown with irregular dark brown blotches; caudal fin dark brown with narrow light brown band on anterior half. Adult specimens about $70 \mathrm{~mm}$ SL with pectoral, pelvic, dorsal, and anal fins light brown with irregular dark brown stripes, first branched rays with small dark brown spot on base and another distally, distal spot usually extended to last ray forming narrow transversal band; caudal fin with small dark brown spot on its base, middle region of branched rays light brown with irregular dark brown stripes, distal portion with broad, transverse, dark brown band, superior and inferior unbranched ray with irregular dark brown dots. See "Remarks" for description of the holotype.

Sexual dimorphism. Dissected females with mature oocytes at about $57 \mathrm{~mm}$ SL. Males showing sexually dimorphic odontodes at about $64 \mathrm{~mm}$ SL. Breeding male specimens with hypertrophied odontodes arranged on lateral margins and dorsum of head,

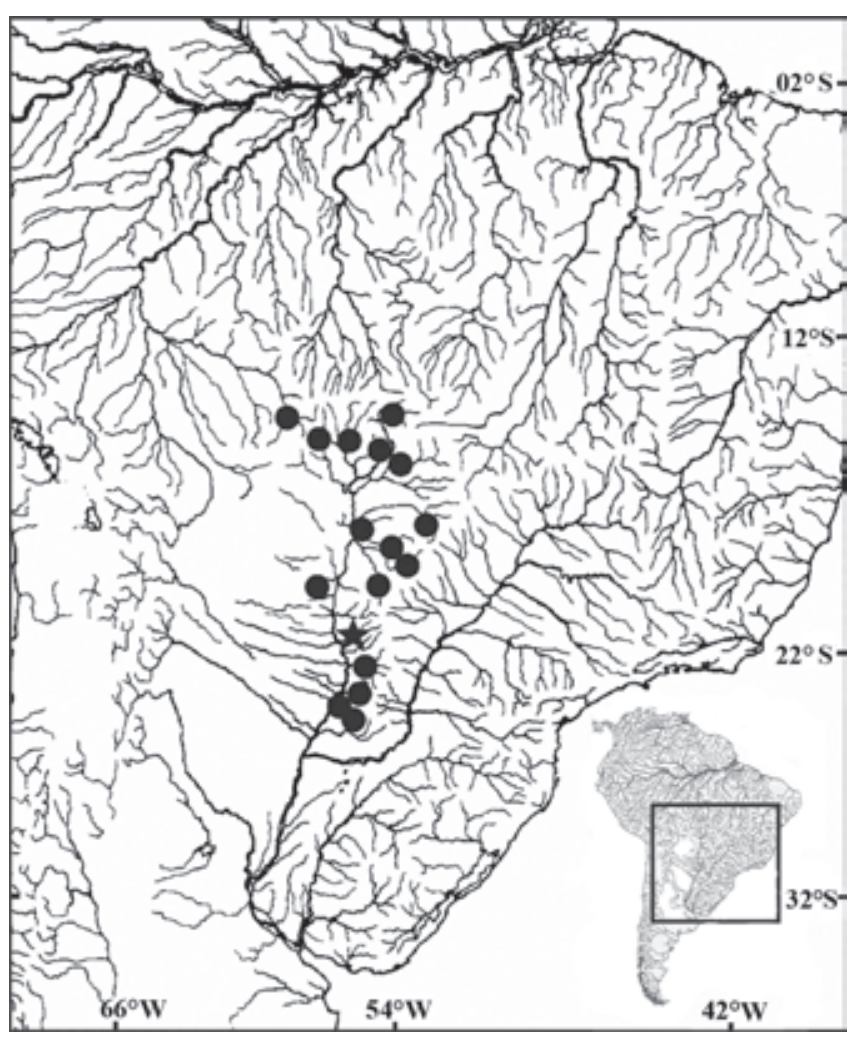

Fig. 5. Partial map of South America showing the geographical distribution of Rineloricaria aurata. . Dot = Occurrence. Star = Type locality (Aquidabán River, Concepción, Departamento de Concepción, Paraguay). 


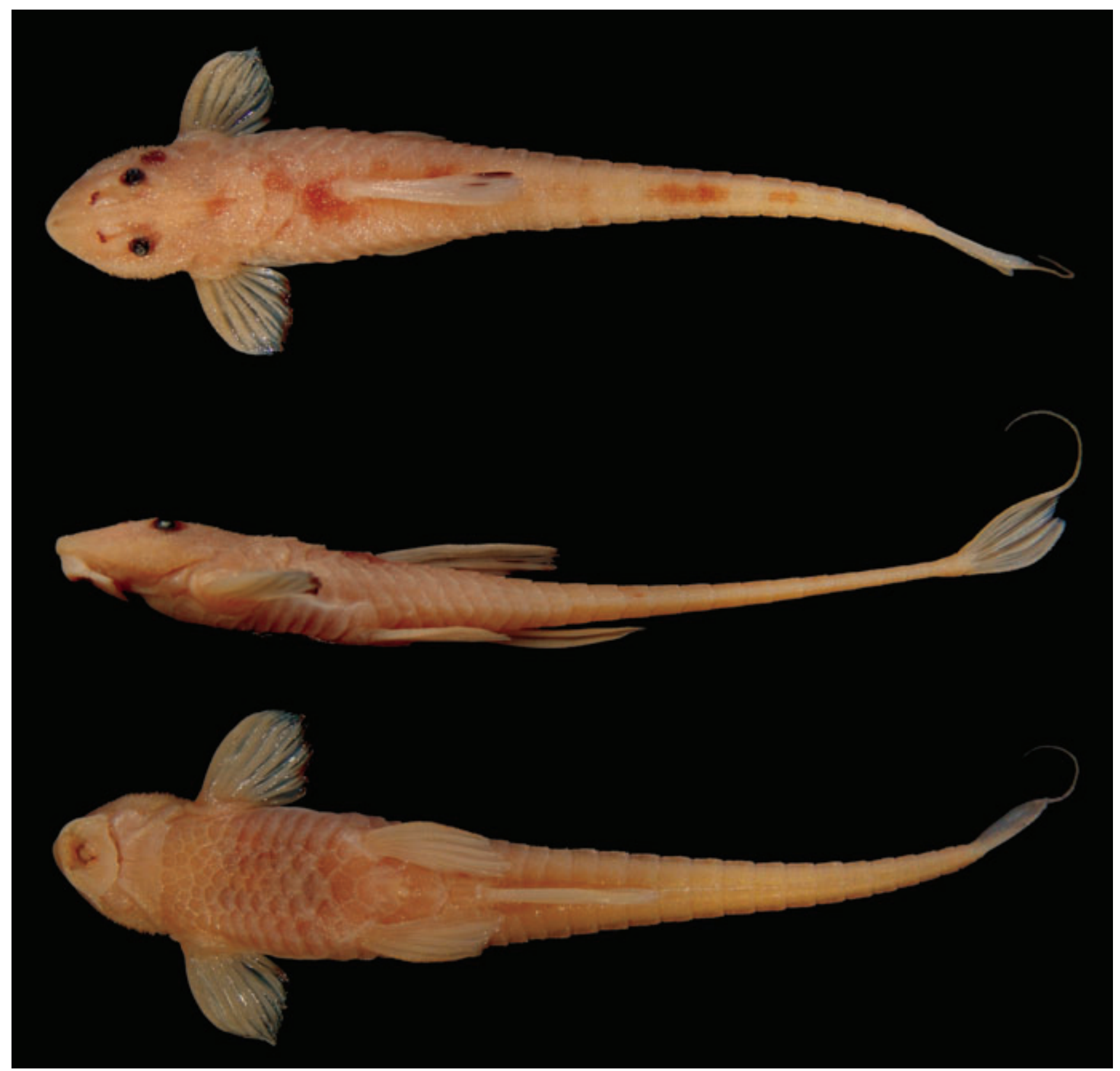

Fig. 6. Holotype of Rineloricaria aurata, ZMA 123591, male, 83.1 mm SL, Aquidabán River, tributary of the Paraguay River, Concepción, Departamento de Concepción, Paraguay.

predorsal plates, and dorsal region of pectoral-fin rays (Fig. 2); premaxillary and dentary teeth having its mesial cusp enlarged and rounded. Apparently, dimorphic odontodes develop first on lateral margins of head and on dorsum of pectoral fin, and later on dorsum of head and predorsal plates. Dimorphic odontodes on dorsum of head and predorsal region straight, thin, long, depressed, usually covered by skin at base, sometimes entirely covered, distributed in a large area over frontal, sphenotic, compound pterotic, parieto-supraoccipital, and predorsal plates. Dimorphic odontodes on lateral margins of head thin and long, tips hook-like curved, usually covered by skin at base, distributed over suprarostral plates, postrostral plates 2, 3, 4, subocular cheek plates 1 , 2, and opercle. Dimorphic odontodes on dorsal region of pectoral branched rays thin, long, curved medially, distributed over almost entire portion of first to fifth rays and usually covered by skin at base; dimorphic odontodes of unbranched rays shorter and more densely arranged.

Distribution and habitat. Rineloricaria aurata is known from the Paraguay River basin in Paraguay and Brazil, and from the Guaporé River in Brazil (Fig. 5). In Paraguay, this species were 
Table 2. Morphometrics of Rineloricaria aurata $\mathrm{n}=$ Number of specimens, SD = Standard deviation.

\begin{tabular}{|c|c|c|c|c|c|c|}
\hline \multirow{2}{*}{$\begin{array}{l}\text { Locality } \\
\text { Characters }\end{array}$} & \multicolumn{3}{|c|}{ Paraguay River basin $(\mathrm{n}=66)$} & \multicolumn{3}{|c|}{ rio Guaporé $(\mathrm{n}=10)$} \\
\hline & Range & Mean & SD & Range & Mean & $\mathrm{SD}$ \\
\hline Standard length (mm) & $54.5-83.5$ & 67.5 & 7.6 & $61.5-81.2$ & 67.1 & $\overline{5.6}$ \\
\hline \multicolumn{7}{|c|}{ Percents of standard length } \\
\hline Head length & 19.3-22.5 & 20.7 & 0.8 & 18.9-21.3 & 20.4 & 0.8 \\
\hline Predorsal length & 27.9-33.3 & 30.3 & 1.2 & 27.5-31.7 & 29.9 & 1.3 \\
\hline Postdorsal length & $64.0-73.3$ & 70.1 & 1.5 & $68.9-72.0$ & 70.3 & 1.1 \\
\hline Prepectoral length & 15.0-18.1 & 16.4 & 0.6 & 15.8-17.5 & 16.3 & 0.6 \\
\hline Postpectoral length & 70.6-86.7 & 84.7 & 2.0 & 83.7-86.8 & 85.6 & 1.0 \\
\hline Prepelvic length & $26.5-32.9$ & 29.6 & 1.2 & $27.2-30.6$ & 29.0 & 1.2 \\
\hline Postpelvic length & 68.3-86.3 & 71.7 & 2.7 & 69.5-75.9 & 72.0 & 1.7 \\
\hline Preanal length & $37.7-45.5$ & 41.9 & 1.7 & $38.5-44.1$ & 41.1 & 1.6 \\
\hline Postanal length & $54.2-70.1$ & 58.6 & 2.7 & $56.8-60.8$ & 58.5 & 1.4 \\
\hline Unbranched dorsal-fin ray & $16.8-22.0$ & 20.0 & 1.0 & 18.7-20.9 & 19.8 & 0.6 \\
\hline Unbranched pectoral-fin ray & $13.1-17.4$ & 15.2 & 0.9 & $14.2-16.3$ & 15.2 & 0.7 \\
\hline Unbranched pelvic-fin ray & 12.9-16.3 & 14.4 & 0.9 & 13.6-15.5 & 14.4 & 0.6 \\
\hline Unbranched anal-fin ray & $15.5-18.8$ & 17.2 & 1.0 & 15.3-17.2 & 16.0 & 0.6 \\
\hline Superior unbranched caudal-fin ray & 30.9-68.4 & 55.8 & 7.8 & 60.3-67.4 & 64.2 & 3.6 \\
\hline Inferior unbranched caudal-fin ray & 12.7-16.5 & 14.3 & 0.8 & 12.8-15.3 & 14.1 & 0.7 \\
\hline Thoracic length & $12.7-17.0$ & 14.7 & 1.0 & 12.8-15.6 & 14.1 & 0.8 \\
\hline Abdominal length & $11.7-15.8$ & 13.7 & 0.9 & $12.4-14.6$ & 13.4 & 0.7 \\
\hline Cleithral width & 11.9-17.1 & 14.2 & 1.3 & 13.3-15.2 & 14.1 & 0.6 \\
\hline Depth at dorsal-fin origin & $6.7-11.0$ & 8.5 & 0.9 & 7.5-9.1 & 8.4 & 0.5 \\
\hline Width at anal-fin origin & 7.5-12.2 & 9.9 & 0.9 & $8.8-11.0$ & 9.8 & 0.7 \\
\hline Caudal peduncle depth & $1.1-1.7$ & 1.4 & 0.2 & $1.2-1.4$ & 1.3 & 0.1 \\
\hline Caudal peduncle width & $2.1-3.2$ & 2.6 & 0.3 & $2.2-2.8$ & 2.4 & 0.2 \\
\hline \multicolumn{7}{|c|}{ Percents of head length } \\
\hline Snout length & $45.4-52.0$ & 48.5 & 1.4 & $47.7-50.8$ & 49.2 & 1.1 \\
\hline Eye diameter & $12.1-18.8$ & 15.3 & 1.6 & $12.8-15.2$ & 14.2 & 0.8 \\
\hline Maximum orbital diameter & $18.4-26.2$ & 22.8 & 1.7 & $19.6-24.3$ & 20.9 & 1.3 \\
\hline Interorbital width & 18.6-29.4 & 25.3 & 1.8 & 24.7-26.9 & 25.5 & 0.7 \\
\hline Internarial width & $6.9-11.2$ & 8.8 & 1.1 & 7.1-10.0 & 8.7 & 1.0 \\
\hline Head depth & $33.0-43.7$ & 39.4 & 2.5 & $36.2-42.2$ & 38.9 & 1.6 \\
\hline Head width & 54.1-81.4 & 64.4 & 6.1 & $60.8-69.9$ & 64.9 & 2.4 \\
\hline Free maxillary barbel & 8.8-20.3 & 13.6 & 2.1 & $10.4-17.0$ & 13.1 & 2.3 \\
\hline Ventrorostral length & $5.3-9.6$ & 7.3 & 1.0 & $5.7-8.9$ & 7.6 & 1.1 \\
\hline Lower lip length & $10.5-18.8$ & 12.7 & 1.5 & 10.3-13.1 & 11.8 & 1.2 \\
\hline
\end{tabular}

collected together with specimens of $R$. lanceolata and Farlowella paraguayensis along of the Jejuí and the Piribebuy drainages associated to leaves of partially submerged plants in small streams of clear and running waters.

Remarks. Knaack (2003) mentioned in the abstract of the original description of Rineloricaria aurata that a uniquely colored mailed catfish is described. This color pattern was characterized by a remarkably gold coloring of body dorsally and ventrally; black stains on dorsal-, pectoral-, ventral-, and anal-fin distal margins; a rounded black spot on the inferior lobe of the caudal fin; and irregular black marks before and below dorsal-fin insertion. The author stated that specimens changed their luminous intensity and mark designs according to environmental alterations of the aquarium and behavior condition, except for a black blotch posterior to the right eye in the holotype. In the preserved holotype, the black spot below right eye is still visible, marks on dorsal and pectoral fins are badly visible, marks before and below dorsal-fin insertion are brown reddish, and marks on nostrils, ventral, anal, and caudal fins are missing (Fig. 6). We conclude that the author was based in peculiarities of the color pattern of one abnormal specimen to diagnose this species, which was preserved as the holotype and the unique type specimen. See "Discussion" for more details.
Examined material. Type specimens: ZMA 123591, holotype, 83.0 mm SL, río Aquidaban, Dpto. de Concepcion, Strecke LoretoSan Carlos, Paraguay. Non-type specimens: Brazil: Mato Grosso State: CPUFMT 301, 11, 47.6-57.4 mm SL, CPUFMT 302, 5, 49.6-61.4 mm SL, CPUFMT 303, 7, 44.5-57.7 mm SL, CPUFMT 304, 2, 49.5-46.0 mm SL, córrego Salobinho, Nobres. CPUFMT 305, 1, $54.7 \mathrm{~mm}$ SL, CPUFMT 306, 1, $71.8 \mathrm{~mm}$ SL, CPUFMT 307, 3, 57.3-59.4 mm SL (plus 1 ex. of $R$. lanceolata), CPUFMT 308, 5, 49.3-62.7 mm SL (plus 3 ex. of $R$. lanceolata), CPUFMT 309, 4, 58.4-68.3 mm SL (plus 2 ex. of $R$. lanceolata), córrego Estorda, Diamantino. CPUFMT 316, 2, 59.9-60.6 mm SL (plus 1 ex. of $R$. lanceolata), córrego Quebra-Canela, Diamantino. MCP 15794, 1, 81.7 mm SL, riacho Zé do Cacete, Cáceres. MCP 36520, 1, 50.5 mm SL, MCP 36525, 7, (1), 31.0-54.4 mm SL, MCP 36526, 1, $44.4 \mathrm{~mm}$ SL, stream of the Poconé Pantanal, Poconé. MCP 36521, 1, (1), $76.8 \mathrm{~mm}$ SL, affluent of the rio Caeté, Cáceres. MCP 36522, 6, (4), 56.6-83.0 mm SL, riacho Figueira, Cáceres. MCP 36523, 3, 42.8-49.9 mm SL, affluent of the rio Aguapeí, Cáceres. MCP 36524, 1, $46.2 \mathrm{~mm}$ SL, affluent of the rio Cuiabá, Várzea Grande. MCP 36535, 7 + 1 c\&s of 13, (1), 46.7-63.3 mm SL, rio Papagaio, Pontes e Lacerda. MCP 36542, 2, (2), 68.3-70.1 mm SL, rio Galera, Pontes e Lacerda. MCP 36543, 17 + 3 c\&s of 37, (5), 51.3-68.8 mm SL, affluent of the rio Guaporé, Pontes e Lacerda. MCP 36546, 5 + 1 c\&s, (2), 44.6-81.4 mm SL, rio Novo, Nova Lacerda. MNRJ 20542, 1, (1), $79.3 \mathrm{~mm}$ SL, MNRJ 20543, 3 of 6, (2), 61.8-74.6 mm SL, affluent of the rio Aricá-Açu, Cuiabá. MNRJ 21072, 1, 24.9 mm SL, rio Mutum, Dom Aquino. MZUEL 5149, 27, 25.2-56.7 mm 
SL, MZUEL 5158, 44, 26.6-51.5 mm SL, MZUEL 5159, 2, 32.440.0 mm SL, stream affluent of the rio Pixaim, Poconé. MZUEL 5151, 1, 47.5 mm SL, small lake of the rio Pixaim, Poconé. MZUSP 35909, 1, $55.0 \mathrm{~mm}$ SL, lake between rio Piquiri and rio Itiquira, Itiquira. MZUSP 44367, 4, 45.1-52.3 mm SL, stream of the Cáceres Pantanal, Cáceres. NUP 1011, 1, 46.2 mm SL, NUP 2269, 9, (3), 31.5-83.2 mm SL, NUP 3440, 5, (2), 63.2-74.1 mm SL, NUP 5407, 6, (1), 53.6-83.8 mm SL, NUP 5408, 5, (1), 62.1-70.6 mm SL, NUP 5409, 3, (2), 49.1-69.8 mm SL, NUP 5410, 4, 49.3-60.3 mm SL, NUP 5413, 3, (1), 55.6-78.5 mm SL, NUP 5414, 12, (1), 41.2-64.4 mm SL, NUP 5415, 5, (2), 56.9-75.7 mm SL, NUP 5416, 21, (1), 44.9-72.3 mm SL, NUP 5419, 3, (1), 59.3-84.7 mm SL, NUP 6111, 1 c\&s, 65.8 mm SL, NUP 6112, 1 c\&s, 85.5 mm SL, córrego Cancela, Nobres. NUP 2265, 1, 72.8 mm SL, NUP 2266, 5, 27.5-76.0 mm SL, NUP 6110, 1 c\&s, 57.1 mm SL, córrego Forquilha, Rosário Oeste. NUP 2267, 1 c\&s, (1), 61.8 mm SL, NUP 5420, 11, 36.549.1 mm SL, córrego Embaúba, Rosário Oeste. NUP 6113, 1, 50.4 mm SL, baía Santo Antônio, Barão de Melgaço. NUP 963, 88, (1), 23.9-74.2 mm SL, NUP 4539, 3, 42.1-48.5 mm SL, Manso Reservoir, Chapada dos Guimarães. Mato Grosso do Sul State: MZUEL 5150, 2, 35.5-37.2 mm SL, affluent of the rio Miranda, Corumbá. MZUEL 5154, 1, 79.4 mm SL, rio Miranda, Corumbá. MZUSP 48319, 3, 44.8-50.3 mm SL, bay at the Paiaguás Pantanal, Coxim. MZUSP 59349, 10 of 26, 34.1-65.4 mm SL, rio Taboco, Aquidauana. MZUSP 59350, 6 (plus 6 ex. of R. parva), 40.0-53.0 mm SL, corixo Santo Antônio, Aquidauana. MZUSP 59368, 1 (plus 1 ex. of R. parva), 42.4 mm SL, rio Abobral 3, Corumbá. MZUSP 59369, 1 (plus 1 ex. of $R$. parva), 46.3 mm SL, rio do Peixe, Corumbá. MZUSP 59676, 10, 40.1-52.5 mm SL (pointed snout), stream of the Nhecolândia Pantanal, rio Negro. NUP 5893, 1, 44.8 mm SL, dike at Transpantaneira Road, Corumbá. ZUFMS-PIS 656, 8 (plus 1 ex. of $R$. parva), 32.1-54.4 mm SL, baía das Pedras, Corumbá. Paraguay: Departamento de Alto Paraguay: MNHNP 3673, 1, 58.2 mm SL, río Paraguay, Fuerte Olimpo. MNHNP 3674, 1, 53.3 mm SL, río Paraguay, Puerto 14 de mayo. NRM 33313, 1 (plus 30 ex. of R. parva), 58.1 mm SL, río Paraguay, Bahia Negra. NRM 37673, 2 (plus 11 ex. of $R$. parva), 52.2-58.5 mm SL, río Paraguay, Bahia Negra. Departamento de Amambay: MNHNP 2662, 5, 44.5-64.5 mm SL, affluent of the río Apa, Bella Vista. Departamento de Caaguazú: NRM 42111, 2, 54.0-67.5 mm SL, affluent of the río Tebicuary-mí, Coronel Oviedo. NRM 42849, 8, (4), 23.5-72.0 mm SL, affluent of the río Yhaguy, San José. Departamento de Canindeyú: MNHNP 474, 2, (1), 42.7-68.4 mm SL, affluent of the río Jejuí, San Isidro de Curuguaty. MNHNP 1589, 1, 46.9 mm SL, tributary of the río Jejuí, San Isidro de Curuguaty. MNHNP 2866, 1, (1), $73.4 \mathrm{~mm}$ SL, affluent of the río Jejuí, Colonia Lomas Valentinas. MNHNP 3608, 1, 53.4, río Jejuí-mí, Reserva Natural del Bosque Mbaracayú. MNHNP 3669, 1 c\&s, 72.0 mm SL, arroyo Pira-Cajón, Reserva Natural del Bosque Mbaracayú. NRM 22472, 1, (1), 66.6 mm SL, NRM 32580, 3, (2), 45.0-59.6 mm SL, río Jejuímí, Curuguaty. UMMZ 206295, 1 (plus 19 ex. of $R$. lanceolata), $42.2 \mathrm{~mm}$ SL, arroyo Carimbatay, Curuguaty. Departamento de Concepción: MNHNP 510, 2, (1), 50.4-65.6 mm SL, Tagatiyá-Mí, Paso Barreto. MNHNP 3664, 3, (1), 47.2-64.4 mm SL, TagatiyáMí, Paso Barreto. MNHNP 3670, 1 c\&s, 67.1 mm SL, affluent of the río Apa, Parque Nacional Paso Bravo. MZUSP 54228, 2, (2), 56.1-62.3 mm SL, río Aquidabán, Concepción. NRM 23028, 1 (plus 11 ex. of $R$. parva), 38.9 mm SL, arroyo Laguna Penayo, Paso Barreto. NRM 32584, 3, (2), 63.9-65.9 mm SL, arroyo Laguna Penayo, Paso Barreto. Departamento de Cordillera: ANSP 164276 , 1, (1), 69.1 mm SL, possibly Caacupé. CZCEN 315, 1 c\&s, 60.2 mm SL, affluent of the río Yhaguy, Caraguatay. MNHNP 3655, 5,
(1), 47.8-60.5 mm SL, MNHNP 3675, 1, 71.4 mm SL, NRM 41822, 3, (1), 46.4-60.3 mm SL, arroyo Piribebuy, Eusebio Ayala. Departamento de Guairá: MNHNP 3676, 2, 39.7-48.0 mm SL, affluent of the río Tebycuary-Mí, Colonia Natalicio Talavera. NRM 42354, 6 (plus 31 ex. of $R$. lanceolata), 21.7-25.9 mm SL, arroyo Guazú, Independencia. Departamento de San Pedro: ANSP 175152, 20, (4), 12.7-76.9 mm SL, swamp of the río Maduvirã, Yataity del Norte. CZCEN 326, 5, 47.6-79.2 mm SL, arroyo Maya, San Pedro del Ycuamandiyú. MNHNP 384, 2, (2), 71.5-73.7 mm SL, río Mboi, Colonia Coé Pytã. MNHNP 385, 2, (2), 69.5-73.5 mm SL, río Mboi, Colonia Coé Pytã. MNHNP 1221, 1, 46.1 mm SL, arroyo Aguaray-Mí. MNHNP 1583, 1, (1), 57.7 mm SL, arroyo Clementina, Santa Rosa. NRM 22285, 1, (1), 71.0 mm SL, río Jejuí, Mbutuy. NRM 33590, 1, 67.9 mm SL, arroyo Clementina, Santa Rosa. UMMZ 206604, 20 of 45, (10), 51.0-75.3 mm SL, río Aguaray, city not specified.

\section{Rineloricaria cacerensis (Miranda Ribeiro, 1912) Fig. 7}

Loricaria cacerensis Miranda Ribeiro, 1912: 11 [original description; syntypes: MNRJ 645 and MNRJ 30030; type locality: Paraguay River, Cáceres, Estado de Mato Grosso, Brazil]. -Miranda Ribeiro, 1953: 400 [designation of lectotype: MNRJ 645].

Rineloricaria cacerensis. -Fowler, 1954: 113 [listed; Paraguay River]. -Isbrücker \& Nijssen, 1976: 111 [listed]. -Isbrücker, 1978: 87 [listed]. -Britski et al., 1999: 130 [short transcription of the original description; Brazilian Pantanal]. -Ferraris, 2003: 341 [listed; Paraguay River basin in Brazil]. -Britski et al., 2007: 160 [short transcription of the original description; Brazilian Pantanal]. -Ghazzi \& Oyakawa, 2007: 90 [listed; upper Paraguay River basin in Brazil].

Hemiloricaria cacerensis. -Isbrücker et al., 2001: 23 [listed]. -Isbrücker, 2001: 27 [listed]. -Ferraris, 2007: 245 [listed; Estado de Mato Grosso, Brazil].

Diagnosis. Rineloricaria cacerensis is distinguished from most of its congeners by having five lateral plate series in longitudinal rows below the dorsal fin, the mid-dorsal series present (Fig. 4c) [vs. four lateral plate series in longitudinal rows below the dorsal fin, the mid-dorsal series absent (Fig. 4a) in $R$. aurata, R. beni, $R$. cadeae, R. castroi, $R$. catamarcensis, $R$. felipponei, $R$. lanceolata, $R$. langei, $R$. longicauda, $R$. magdalenae, $R$. misionera, $R$. nigricauda, $R$. pareiacantha, $R$. parva, $R$. quadrensis, $R$. sanga, $R$. setepovos, $R$. sneiderni, R. stellata, R. strigilata, $R$. thrissoceps, $R$. uracantha, and $R$. wolfei]; and by presenting the lateral region of the body posterior to the pectoral-fin insertion with a slender area of naked skin, narrower than the caudal peduncle width (Fig. 4c) [vs. with a broad area of naked skin, similar in thickness to the caudal peduncle width (Fig. 4a) in $R$. aequalicuspis, $R$. anhanguapitan, $R$. anitae, $R$. baliola, $R$. capitonia, $R$. isaaci, $R$. jaraguensis, $R$. kronei, $R$. latirostris, R. maacki, R. malabarbai, $R$. maquinensis, $R$. microlepidogaster, $R$. pentamaculata, $R$. reisi, $R$. rupestris, $R$. stewarti, and $R$. tropeira]. It is distinguished from remaining members of the genus, except $R$. daraha, $R$. fallax, $R$. formosa, 


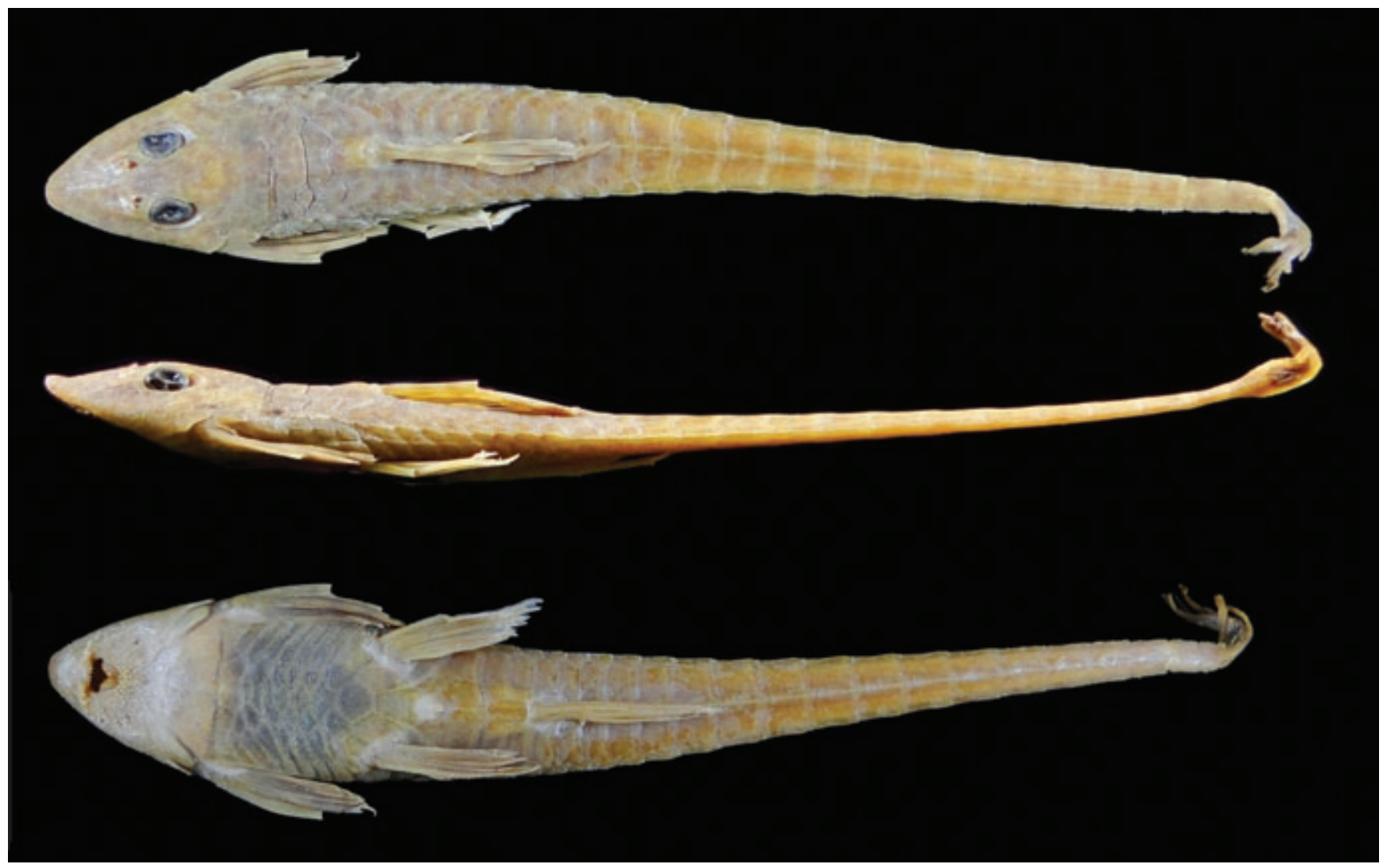

Fig. 7. Lectotype of Rineloricaria cacerensis, MNRJ 645, 67.7 mm SL, Paraguay River basin, Cáceres, Mato Grosso State, Brazil.

R. hasemani, R. jubata, R. melini, R. morrowi, R. osvaldoi, $R$. teffeana, and $R$. zaina, by having the lateral plate of the middorsal series consisting in five to seven keeled plates extended posteriorly around end of the dorsal-fin base (Fig. 4c) [vs. lateral plate of the mid-dorsal series consisting in two keeled plates situated around insertion of first ray of the dorsal fin (Fig. 4b) in R. altipinnis, R.caracasensis, R. eigenmanni, $R$. heteroptera, R. konopickyi, R. phoxocephala, R. platyura, and $R$. steindachneri]. It is distinguished from $R$. daraha, $R$. osvaldoi, and $R$. zaina by having three longitudinal series of abdominal plates on the median complex (vs. several unorganized abdominal plates on the median complex in $R$. daraha; five longitudinal series of abdominal plates on the median complex in $R$. osvaldoi and $R$. zaina). It is distinguished from $R$. fallax, $R$. formosa, R. hasemani, R. jubata, R. melini, $R$. morrowi, and $R$. teffeana by the caudal fin coloring, consisting in a plain dark brown caudal fin on branched rays and membranes, and a barred superior and inferior unbranched rays (vs. caudal fin excepting outer unbranched rays with a small black stain at its base followed by a broad light-colored area with dark bars on rays and a terminal black margin in R. hasemani, R. jubata, R. melini, R. morrowi, and $R$. teffeana; caudal fin dark brown with vertical darker bars on rays in $R$. fallax and $R$. formosa). It is further distinguished from $R$. fallax, $R$. formosa, R. hasemani, R. jubata, R. morrowi, and $R$. teffeana by having the dorsum of body with large irregular spots (vs. dorsum with a single predorsal spot in $R$. fallax; dorsum with small spots in R. formosa and R. morrowi; and dorsum without spots in $R$. hasemani, $R$. jubata, and $R$. teffeana); and from $R$. melini by having the dorsum of head without dark cross bars (vs. head with four dark cross bars).

Description. Morphometric data presented in Table 3. Snout tip raised in lateral view. Dorsal profile from snout tip to posterior nasal plates straight, convex from frontals to nuchal plate, declined at dorsal-fin base, straight from end of dorsalfin base to penultimate dorsal plate, caudal fin damaged on three syntypes. Ventral profile from snout tip to anal-fin base convex, straight from that point to penultimate ventral plate, caudal fin damaged on three syntypes.

Snout tip pointed in dorsal view, lateral margins of head curved anteriorly. Odontodes of head and trunk small, thick, aligned. Dorsum of head smooth, without ridges. Infraorbital series with six bones, infraorbital 1 with a sensorial pore exposed ventrally, infraorbitals 2,3 , and 4 convexly raised from anterior portion of snout to eye. Rostral plate with an area of naked skin without odontodes at tip of snout, narrow, horizontally elongated, short, not reaching sensorial pore ventrally exposed of infraorbital 1. Posterior margin of parietosupraoccipital slightly concave to straight, lateral margins 
Table 3. Morphometrics of Rineloricaria cacerensis. $\mathrm{n}=$ Number of specimens.

\begin{tabular}{lccc}
\hline \multicolumn{1}{c}{ Locality } & \multicolumn{3}{c}{ rio Cáceres (n=3) } \\
\hline Characters & Lectotype & Range & Mean \\
\hline Standard length (mm) & 67.7 & $55.0-67.7$ & 59.7 \\
& Percents of standard length & & \\
Head length & 12.4 & $18.4-20.1$ & 19.1 \\
Predorsal length & 17.9 & $26.4-28.9$ & 27.8 \\
Postdorsal length & 49.8 & $73.5-74.5$ & 73.8 \\
Prepectoral length & 10.4 & $15.4-16.1$ & 15.7 \\
Postpectoral length & 57.5 & $84.9-88.3$ & 86.6 \\
Prepelvic length & 17.6 & $25.4-26.0$ & 25.6 \\
Postpelvic length & 50.3 & $73.9-76.1$ & 74.7 \\
Preanal length & 25.6 & $37.8-38.8$ & 38.3 \\
Postanal length & 42.7 & $62.0-63.1$ & 62.7 \\
Unbranched dorsal-fin ray & - & 18.7 & 18.7 \\
Unbranched pectoral-fin ray & - & 15.6 & 15.6 \\
Unbranched pelvic-fin ray & 10.0 & $12.0-14.7$ & 13.4 \\
Unbranched anal-fin ray & 10.7 & $12.4-15.8$ & 14.1 \\
Superior unbranched caudal-fin ray & - & - & - \\
Inferior unbranched caudal-fin ray & - & - & - \\
Thoracic length & 7.9 & $11.6-12.0$ & 11.7 \\
Abdominal length & 8.5 & $12.5-13.9$ & 13.3 \\
Cleithral width & 9.4 & $13.6-14.0$ & 13.9 \\
Depth at dorsal-fin origin & 4.8 & $7.0-7.1$ & 7.1 \\
Width at anal-fin origin & 6.5 & $8.5-10.0$ & 9.4 \\
Caudal peduncle depth & 0.8 & $1.0-1.2$ & 1.1 \\
Caudal peduncle width & 1.7 & $2.3-2.8$ & 2.5 \\
& Percents of head length & & \\
Snout length & 6.1 & $44.5-48.8$ & 46.8 \\
Eye diameter & 2.4 & $19.5-20.2$ & 19.8 \\
Maximum orbital diameter & 3.0 & $23.3-24.8$ & 24.1 \\
Interorbital width & 2.3 & $18.6-21.1$ & 19.5 \\
Internarial width & 1.4 & 10.9 & 10.9 \\
Head depth & 4.8 & $32.3-38.7$ & 36.3 \\
Head width & 8.4 & $58.4-67.3$ & 63.3 \\
Free maxillary barbel & 1.3 & 10.2 & 10.2 \\
Ventrorostral length & 1.2 & $8.8-10.9$ & 9.6 \\
Lower lip length & 1.9 & $13.3-15.1$ & 14.2 \\
\hline & & & \\
& & & \\
& & &
\end{tabular}

truncate. Predorsal plates and first three lateral plates of dorsal series with ridges or keels moderately developed. Superior margin of orbit slightly raised, postorbital notch large. Eye large, rounded to slightly oval horizontally.

Lower lip narrow, ventral surface covered by short papillae with rounded tip, papillae slightly bigger close to dentary. Lower lip margin with long fringes; upper lip margin with short fringes. Maxillary barbel long, surpassing distal border of lower lip. Teeth bicuspid, long, mesial cusp greater and wider than lateral, dentary teeth larger than premaxillary. Premaxilla with 4(1) or 6*(2) teeth; dentary with 7(1), 8(1), or 9*(1) teeth. Sexual dimorphism on teeth not seen (see sexual dimorphism).

Body narrow and long, five lateral plate series in longitudinal rows below the dorsal fin: dorsal, mid-dorsal, median, mid-ventral, and ventral. Mid-dorsal series with moderately-developed keels, last plate extended around end of dorsal fin. Median and mid-ventral series with rough welldeveloped keels, last plate of mid-ventral series extended around end of anal fin. Median series bearing sensory canal between two proximate keels on caudal peduncle. Longitudinal lateral plates $30(1)$ or $31^{*}(2)$; posterior plates of median series 15(1) or 16*(2). Lateral line complete. Lateral abdominal plates $6 *(46)$. Lateral region of body posterior to pectoral-fin insertion between borders of lateral plates of mid-ventral series and of lateral abdominal plates with a slender area of naked skin, narrower than caudal peduncle width. Abdominal plates of posterior complex with a large well-defined preanal plate bordered by three plates and these by five plates. Abdominal plates of median complex parallel and longitudinally arranged in three series posteriorly and increasing series anteriorly. Abdominal plates of anterior complex irregular, smaller anteriorly, projected toward lip; anterior margin convex, surpassing horizontal line of anterior margin of cleithrum exposed ventrally.

Dorsal fin ii, $7^{*}(3)$, dorsal-fin spinelet present, locking mechanism not functional; depressed unbranched ray reaching fifth plate posterior to its base; depressed last branched ray reaching third or fourth plate. Pectoral fin i,6*(3); depressed unbranched ray evidently surpassing pelvic-fin origin; distal margin truncate. Pelvic fin i,5*(3); depressed unbranched ray slightly surpassing anal-fin origin; distal margin truncate. Anal fin i, $5^{*}(3)$; depressed unbranched ray reaching sixth plate posterior to its base; depressed last branched ray reaching third plate; distal margin truncate. Caudal fin damaged.

Color in alcohol. Based on lectotype and two paralectotypes, which are poorly preserved (color of specimens as originally described on "Remarks"). Dorsal surface of body with dark brown ground coloration; same coloring on ventral surface. Dorsal surface of head from anterior margin of snout to last dorsal plate with large and irregular dark brown spots in lectotype, small and irregular spots visible only on head in paralectotypes. Dorsal and pectoral fins with dark brown bars on rays, pectoral-fin membranes with dark brown pigments, caudal fin uniformly dark brown pigmented on branched rays and membranes, unbranched rays pale brown.

Sexual dimorphism. No sexual dimorphism is known.

Distribution and habitat. Rineloricaria cacerensis is known from its type locality, Cáceres, Mato Grosso State, Brazil (Paraguay River basin). See additional comments on Discussion.

Remarks. The lectotype and paralectotypes of Rineloricaria cacerensis are highly discolored, with the caudal fin partly damaged not allowing confirmation of some characters related to caudal-fin filaments and color pattern mentioned in the original description of Miranda Ribeiro (1912). The caudal fin was described with the external rays prolonged as in R. parva, but with the superior one much longer. The dorsal overall ground coloration was described as light brown (pardo barrento); with a stripe on head around eyes; a blotch on predorsal region (triângulo cervical); five black transversal bands, the first around dorsal-fin insertion, the second broader and located posteriorly to dorsal fin, the remaining three equidistantly on caudal peduncle; caudal fin black, excepting outer rays; and dorsum of body 
from head to end of caudal peduncle with black spots, a series of larger black spots behind dorsal-fin insertion along midline. Unfortunately, the caudal fins of the lectotype and paralectotypes are broken, but we suspect that it should be interpreted as only the superior unbranched ray extended as a long filament. During this revision, we examined numerous species of Rineloricaria and found filaments on both unbranched rays only in $R$. parva, $R$. castroi, and $R$. wolfei. These species presents both caudal unbranched rays extended as long filaments of similar lengths (see Fig. 11), and also other characters as short sexually- dimorphic odontodes on lateral margins of the head and dorsum of pectoral fins in breeding male specimens, four lateral plate series, snout tip not raised, straight lateral margins of the head. However, species of Rineloricaria with five lateral plate series, snout tip raised, and lateral margins of the head curved anteriorly were found in $R$. fallax, $R$. formosa, $R$. hasemani, and $R$. morrowi. These species presented the caudal fin with only the superior unbranched ray extended as a long filament. Because $R$. cacerensis also present these charaters we suspect that the caudal fin could be similar. The stripes around eyes are no longer visible on lectotype and paralectotypes, and we do not know if they were arranged as vertical stripes or as horizontal cross bands.

Examined material. Type specimens: MNRJ 645, lectotype, (1), 67.7 mm SL, Cáceres, Mato Grosso (Aguas do Paraguay), Brazil. MNRJ 30030, paralectotypes, (2), 55.0-56.4 mm SL, same data of lectotype.

\section{Rineloricaria lanceolata (Günther, 1868) Figs. 8, 9, 10}

Loricaria lanceolata Günther, 1868a: 477 [original description; holotype: BMNH 1867.6.13.79; type locality: affluent of the Aipena River, tributary to the Huallaga River, Marañón River basin, Jeberos, Departamento de Loreto, Peru]. -Günther, 1868b: 235, fig. 3 [expanded description of the holotype with dorsal, lateral and ventral drawings]. -Miranda Ribeiro, 1911: 128, fig. 70 [key of species; reproduction of description and figure of Günther (1868b); senior synonym of Loricaria teffeana].

Loricaria Rhineloricaria [sic] lanceolata. -Regan, 1904: 277 [listed; upper Amazonas River; key of species; description].

Loricaria hoehnei Miranda Ribeiro, 1912: 11 [original description; holotype: MNRJ 650; type locality: drainage of the Taquari River, Paraguay River basin, Coxim, Estado de Mato Grosso do Sul, Brazil]. NEW SYNONYM.

Rineloricaria lanceolata. -Fowler, 1954: 116, fig. 720 [listed; upper Amazonas River basin in Ecuador, Peru, and Bolivia; drawing based on the Günther's original figure]. -Isbrücker, 1973: 75 [redescription; sexual dimorphism; drawing of the dentition]. -Isbrücker \& Nijssen, 1976: 120 [listed; measurements of the holotype; comparison with Rineloricaria heteroptera]. -Isbrücker, 1978: 87 [listed; comments about generic status]. -Isbrücker \& Nijssen, 1992: 29, figs. 34-35 [sexual dimorphism; pictures of specimens from the Pastaza River, Ecuador]. -Chernoff et al., 2001: 146 [listed; Apa and La Paz rivers, Paraguay]. Ferraris, 2003: 342 [listed; Amazonas River basin, Peru]. Knaack, 2003: 57 [picture of a specimen from the Aquidabán River, Paraguay]. -Vera \& Castillo, 2006: 56 [listed; Paraguay River, Paraguay]. -Ghazzi \& Oyakawa, 2007: 90 [listed; Amazonas River basin, Brazil].

Rineloricaria hoehnei. -Isbrücker \& Nijssen, 1976: 112 [listed]. -Isbrücker, 1978: 87 [listed]. -Ferraris, 2003: 342 [listed; Paraguay River basin, Brazil].

Hemiloricaria hoehnei. -Isbrücker et al., 2001: 23 [listed]. Isbrücker, 2001: 27 [listed]. -Ferraris, 2007: 245 [listed; Paraguay River basin, Brazil].

Hemiloricaria lanceolata. -Isbrücker et al., 2001: 23 [listed]. -Isbrücker, 2001: 27 [listed]. -Rodriguez \& Miquelarena, 2002: 159 [morphometry; pictures; Paraná River, Argentina]. -López et al., 2003: 45 [listed; Paraná-Paraguay River drainage]. -Menni, 2004: 79, 95 [listed; Paraná River, Argentina]. -Ferraris, 2007: 246 [listed; upper Amazonas River, Peru].

Diagnosis. Rineloricaria lanceolata is distinguished from most of its congeners by having four lateral plate series in longitudinal rows below the dorsal fin, the mid-dorsal series absent (Fig. 4a) [vs. five lateral plate series in longitudinal rows below the dorsal fin, the mid-dorsal series present and consisting in two to ten keeled plates situated below the dorsal series and beginning around insertion of the first dorsal-fin ray (Fig. 4b and 4c) in R. aequalicuspis, R. altipinnis, $R$. anhanguapitan, $R$. anitae, $R$. baliola, $R$. cacerensis, $R$. capitonia, $R$. caracasensis, $R$. daraha, $R$. eigenmanni, $R$. fallax, $R$. formosa, $R$. hasemani, $R$. heteroptera, $R$. isaaci, $R$. jaraguensis, $R$. jubata, $R$. konopickyi, $R$. kronei, $R$. latirostris, $R$. maacki, $R$. malabarbai, $R$. maquinensis, $R$. melini, $R$. microlepidogaster, $R$. morrowi, $R$. osvaldoi, R. pentamaculata, $R$. phoxocephala, $R$. platyura, $R$. reisi, $R$. rupestris, $R$. steindachneri, $R$. stewarti, $R$. teffeana, $R$. tropeira, and $R$. zaina]; and by presenting breeding male specimens with sexually dimorphic odontodes on the dorsum of the head and predorsal region (Fig. 8) [vs. sexually dimorphic odontodes absent on dorsum of the head and predorsal region (Fig. 12) in $R$. cadeae, $R$. castroi, $R$. catamarcensis, $R$. langei, $R$. lima, $R$. longicauda, $R$. misionera, $R$. nigricauda, $R$. pareiacantha, $R$. parva, $R$. quadrensis, $R$. sanga, $R$. setepovos, $R$. stellata, $R$. strigilata, $R$. uracantha, and $R$. wolfei]. It is distinguished from remaining members of the genus by having all fins with a broad longitudinal dark band running parallel to the first rays (Fig. 8) [vs. fins irregularly spotted or with a transversal distal band in R. aurata, $R$. beni, $R$. felipponei, $R$. kronei, $R$. magdalenae, $R$. sneiderni, and $R$. thrissoceps].

Description. Morphometric data presented in Table 4. Snout tip straight in lateral view, not raised. Dorsal profile from snout tip to nuchal plate convex, declined at dorsal-fin base, straight 

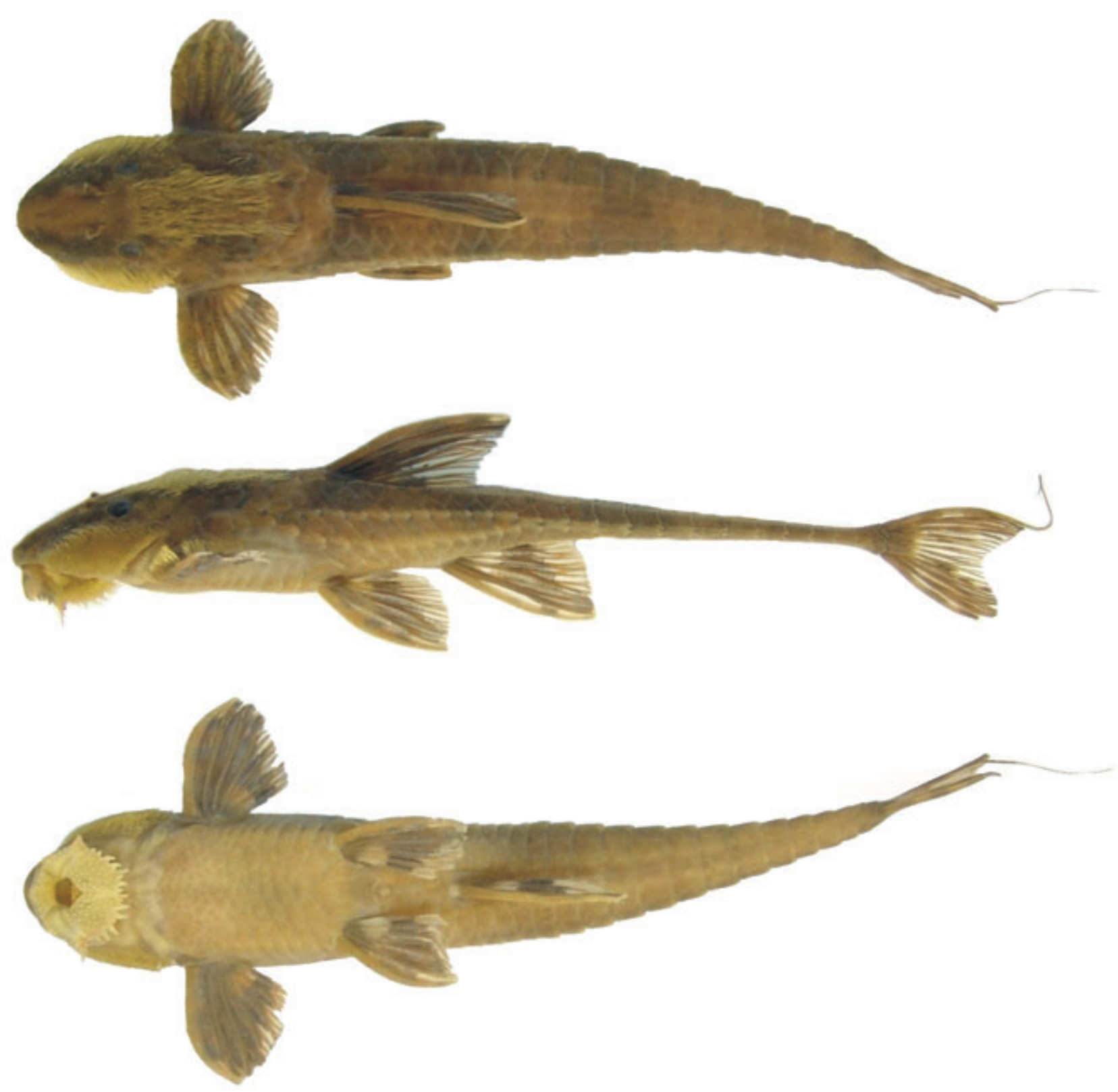

Fig. 8. Rineloricaria lanceolata, CZCEN 316, male, 87.1 mm SL, arroyo Piribebuy, Paraguay River basin, Eusebio Ayala, Departamento de Cordillera, Paraguay.

from dorsal-fin end to penultimate dorsal plate, elevated from last dorsal plate to end of caudal fin. Ventral profile from snout tip to anal-fin base convex, straight from that point to penultimate ventral plate, declined from last ventral plate to end of caudal fin.

Snout tip rounded in dorsal view, lateral margins of head straight. Odontodes of head and trunk small, thick, not aligned. Dorsum of head slightly rough; parieto-supraoccipital with indistinct ridges. Infraorbital series with six bones, infraorbital 1 with a sensorial pore exposed ventrally, infraorbitals 2, 3, and 4 not raised. Rostral plate with an area of naked skin without odontodes at tip of snout, narrow, horizontally elongated, very short, not reaching sensorial pore ventrally exposed of infraorbital 1. Posterior margin of parietosupraoccipital slightly concave to straight; lateral margins truncate. Predorsal plates and first three lateral plates of dorsal series with ridges or keels moderately developed. Superior margin of orbit not raised; postorbital notch small. Eye small, rounded to slightly oval horizontally.

Lower lip narrow, ventral surface covered by short papillae with rounded tip; papillae slightly bigger at line bordering upper lip and close to dentary. Lower lip margin with long 


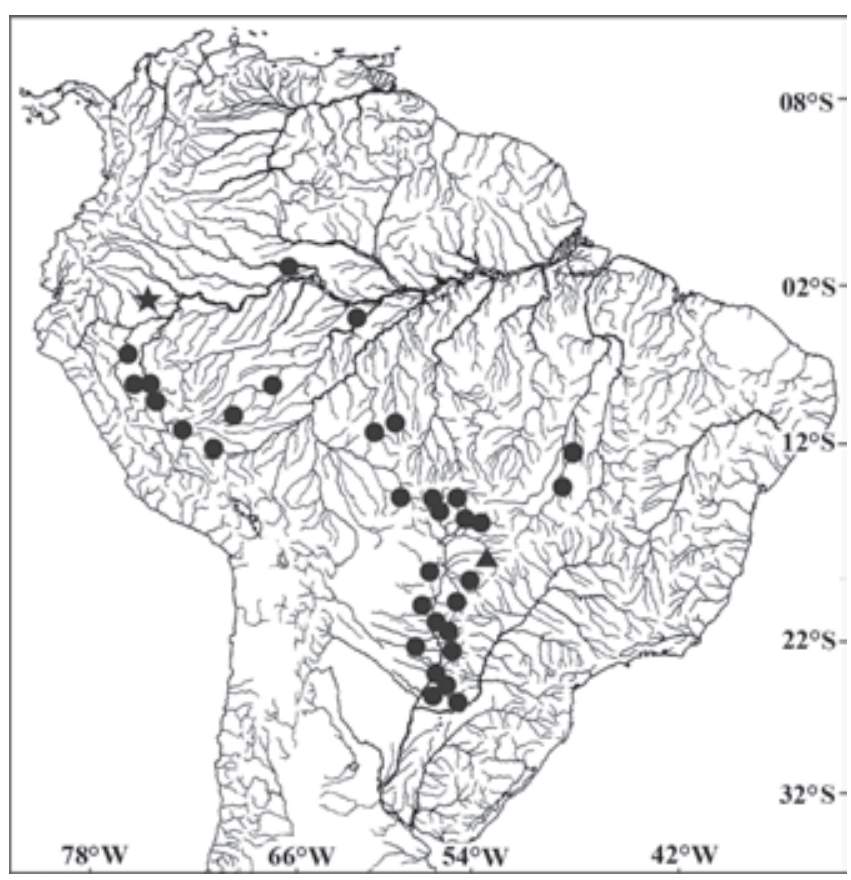

Fig. 9. Partial map of South America showing the geographical distribution of Rineloricaria lanceolata . Dots = Occurrence. Star $=$ Type locality (Jeberos, Departamento de Loreto, Peru). Triangle $=$ Type locality of Loricaria hoehnei (Coxim, Mato Grosso do Sul State, Brazil).

fringes alternating some shorter; upper lip margin with short fringes. Maxillary barbel long, surpassing distal border of lower lip. Teeth bicuspid, long, mesial cusp greater and wider than lateral, dentary teeth larger than premaxillary. Premaxilla with 6(38), 7(26), or 8(7) teeth; dentary with 5(2), 6(33), 7(55), or 8(8) teeth. Sexual dimorphism on teeth present (see sexual dimorphism). Branchiostegal rays 4(17).

Body wide and short, four lateral plate series in longitudinal rows below dorsal fin: dorsal, median, mid-ventral and ventral; mid-dorsal series absent. Median and mid-ventral series with rough well-developed keels; last plate of mid-ventral series extended around end of anal fin. Median series bearing sensory canal between two proximate keels on caudal peduncle. Longitudinal lateral plates 29(3), 30(36), 31(53), 32(11), or 33(1); posterior plates of median series 13(3), 14(26), 15(36), 16(33), or 17(6). Lateral line complete. Lateral abdominal plates 5(6), 6(23), 7(49), 8(20), or 9(6), borders of plates not in contact with lateral plates of mid-ventral series. Lateral region of body posterior to pectoral-fin insertion with a broad area of naked skin, thickness similar to caudal peduncle width, situated along borders of lateral plates of mid-ventral series and of lateral abdominal plates (as shown on Fig. 4a). Abdominal plates of posterior complex with a large welldefined preanal plate bordered by three plates and these by five plates, sometimes divided in smaller plates. Abdominal plates of median complex parallel and longitudinally arranged in three series increasing in number toward anterior complex.
Abdominal plates of anterior complex irregular, smaller than other plates, not projected toward lip; anterior margin convex, slightly surpassing horizontal line of anterior margin of cleithrum exposed ventrally. Vertebrae 25(1), 26(9), or 27(7); ribs $4(14)$ or $5(4)$.

Dorsal fin ii,6(2), ii,7(101), or ii,8(1); dorsal-fin spinelet present, locking mechanism not functional; depressed unbranched ray reaching fifth plate posterior to its base, depressed last branched ray reaching third plate; distal margin truncate. Pectoral fin i,5(1), i,6(100), or i,7(3); depressed unbranched ray slightly surpassing pelvic-fin origin; distal margin truncate. Pelvic fin i,5(104); depressed unbranched ray slightly surpassing anal-fin origin; distal margin truncate. Anal fin i,5(103); depressed unbranched ray reaching fifth plate posterior to its base; depressed last branched ray reaching third plate; distal margin truncate. Caudal fin emarginated, $\mathrm{i}, 7, \mathrm{i}(1), \mathrm{i}, 8, \mathrm{i}(1)$, or i,10,i(102); superior unbranched ray extended as long filament, inferior unbranched ray not extended as filament, only sometimes extended as very short filament.

Color in alcohol. Dark brown or black dots over dorsal suface of body; overall ground coloration light or dark brown; ventral surface light brown. Sometimes clearer ground coloration of anterior region of body with many small dark dots, posterior region of dorsal surface totally black, and abdominal region with irregular dark brown blotches. Dorsal surface of head and predorsal region with two longitudinal dark brown to black bands, running from snout tip through eyes and second predorsal plate; narrow dark brown or black stripes running parallel and below former bands from snout tip to eyes. Lateral margins of head between infraorbital 4 and subocular cheek plate 1 with dark brown or black stripe; opercle and compound pterotic with irregular dark brown or black dots. Pores of sensorial canal of head and anterior lateral line highlighted by black pigments. Dorsal surface of upper lip with two longitudinal brown stripes, dorsal surface of lower lip with a transverse brown stripe. Dorsal surface of trunk with four to six wide, transverse, dark brown or black bands; first at dorsalfin origin, oblique, extending toward last pectoral-fin ray; second just behind dorsal-fin base; following bands similar, equidistantly separated and lighter. All unbranched fin rays light or dark brown with narrow dark brown or black stripes. Pectoral, pelvic, dorsal, and anal fins with broad longitudinal dark brown or black band running parallel to first two or three rays; last rays with narrow, transverse, dark brown or black stripe on their middle length leaving hyaline areas on extremities. Sometimes, all fins black with narrow hyaline distal area on last rays. Caudal fin with longitudinal, dark brown or black band on first and last three branched rays; light brown area on four median rays usually with irregular dark stripes.

Sexual dimorphism. Dissected females with mature oocytes at about $77 \mathrm{~mm}$ SL. Males showing sexually dimorphic odontodes at about $71 \mathrm{~mm}$ SL. Breeding male specimens with hypertrophied odontodes arranged on lateral margins and dorsum of head, predorsal plates, and dorsal region of pectoral-fin rays (Fig. 8); 


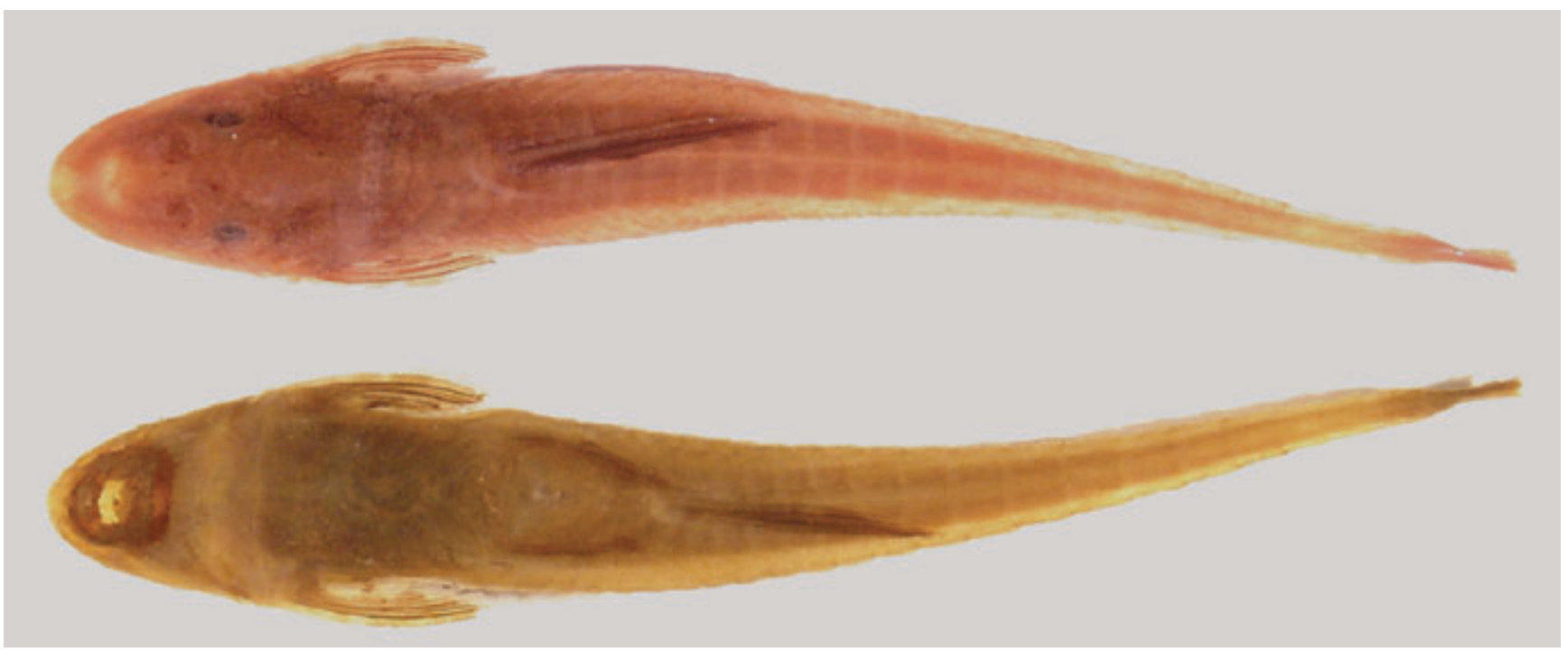

Fig. 10. Holotype of Rineloricaria hoehnei, MNRJ 650, 46.8 mm SL, Coxim, Mato Grosso do Sul State, Brazil.

premaxillary and dentary teeth having its mesial cusp enlarged and rounded. Apparently, dimorphic odontodes develop first on lateral margins of head and on dorsum of pectoral fin, and later on dorsum of head and predorsal plates. Dimorphic odontodes on dorsum of head and predorsal region straight, thin, long, depressed, usually covered by skin at base, sometimes entirely covered, distributed in a large area over frontal, sphenotic, compound pterotic, parieto-supraoccipital, and predorsal plates. Dimorphic odontodes on lateral margins of head thin and long, tips hook-like curved, usually covered by skin at base, distributed in a large area below sensorial canal of infraorbital series over suprarostral plates, infraorbital 1 , postrostral plates 2, 3, 4, subocular cheek plates 1 , 2, and opercle. Dimorphic odontodes on dorsal region of pectoral branched rays thin, long, curved medially, covering almost entire portion of first to fifth rays and usually covered by skin at base; dimorphic odontodes over unbranched ray shorter and more densely arranged.

Distribution and habitat. Rineloricaria lanceolata is known from the Amazonas (including the rios Madeira and Purus); the Paraguay; and the Araguaia river basins (Fig. 9). Specimens from the Branco River in Guyana were also reported in Isbrücker (1973). Specimens of $R$. lanceolata were collected together with specimens of $R$. aurata and Farlowella paraguayensis along of the Jejuí and the Piribebuy drainages (Paraguay River basin in Paraguay) associated to leaves of partially submerged plants in small streams of clear and running waters.

Examined material. Type specimens: BMNH 1867.6.13.79, holotype of Loricaria lanceolata, $82.7 \mathrm{~mm}$ SL, Xeberos, Peru. MNRJ 650, holotype of Loricaria hoehnei, $46.8 \mathrm{~mm}$ SL, Coxim, rio Paraguay, Brazil. Non-type specimens: Brazil: Acre State: MCP 36456, $4+1$ c\&s, (3), 29.7-84.8 mm SL, riacho Entrocamento, Epitaciolândia.
Amazonas State: MCP 36453, 6, (2), 39.4-91.4 mm SL, igarapé São João, Humaitá. MZUSP 23379, 3 of 5, 2 + 1 c\&s, (3), 82.4-91.4 mm SL, igarapé Manduaçu, Fonte Boa. Goiás State: MZUSP 89345, 18 + 2 c\&s of 79, (7), 58.8-98.7 mm SL, riacho Taboca, Crixás. Mato Grosso State: CPUFMT 300, 1, 64.0 mm SL, córrego Salobinho, Nobres. CPUFMT 307, 1, $52.7 \mathrm{~mm}$ SL (plus 3 ex. of R. aurata), córrego Estorda, Diamantino. CPUFMT 308, 3, 46.7-56.4 mm SL (plus 5 ex. of $R$. aurata), córrego Estorda, Diamantino. CPUFMT 309, 2, 47.4-60.5 mm SL (plus 4 ex. of $R$. aurata), córrego Estorda, Diamantino. CPUFMT 316, 1, 57.4 mm SL, córrego Quebra-canela, Diamantino. CPUFMT 317, 6, 48.3-81.4 mm SL, córrego QuebraCanela, Diamantino. CPUFMT 318, 1, 53.6 mm SL, córrego Estorda, Diamantino. DZSJRP 1567, 4, 38.6-70.9 mm SL, riacho do Mato, Alto Taquari. MCP 15685, 1, 76.8 mm SL (estimated, caudal fin regenerated), stream at Barra do Bugres/Cáceres Road (rio Paraguay basin), Barra do Bugres. MCP 15795, 2, 46.1-61.2 mm SL, stream at Barra do Bugres/Cáceres road (about 99 km South of Barra do Bugres, Paraguay River basin), Cáceres. MCP 26076, 1, 51.8 mm SL, riacho Curupira (Paraguay River basin), Barra do Bugres. MCP 36454, 7 of 12, 5 + 2 c\&s, (7), 70.6-91.2 mm SL, riacho Retiro (tributary of the rio Guaporé). MCP 36480, 2, 43.9-49.5 mm SL, rio Pari, Várzea Grande. MCP 36486, 2 + 1 c\&s, (3), 70.2-91.2 mm SL, rio Pindaituba (tributary of the rio Guaporé), Pontes e Lacerda. MCP 36491, 1, (1), 78.4 mm SL, rio Sangradouro, Cáceres. MNRJ 20561, 5, rio AricaMirim, Santo Antônio do Leverger. MNRJ 23146, 1, (1), 74.3 mm SL, rio Serragem II, Nobres. MNRJ 25254, 3, 26.4-47.8 mm SL, riacho Cachoeira ou João Baiano, Água Boa. MZUEL 3824, 21 + 1 c\&s, (10), 51.3-93.3 mm SL, riacho Salobro, Porto Estrela. MZUSP 44331, 4, (2), 55.6-67.7 mm SL, stream at Tangará da Serra/Barra do Bugres road (about 13 km South of Nova Olímpia, Paraguay River basin), Nova Olímpia. MZUSP 37643, 5 + 1 c\&s of 11, (2), 35.9$87.7 \mathrm{~mm}$ SL, stream at Cuiabá/Porto Velho road (about $7 \mathrm{~km}$ after Pontes e Lacerda entrance, tributary of the rio Guaporé), Pontes e Lacerda. MZUSP 37817, 1, 70.1 mm SL, riacho Ingazeiro, Aripuanã. MZUSP 44478, 1, 46.7 mm SL, riacho das Flechas, Cáceres. MZUSP 78812, 3, (1), 16.5-84.5 mm SL, riacho Lagoinha, Araputanga. NUP 2951, 1 c\&s, 89.4 mm SL, rio Cuiabá, Rosário Oeste. NUP 5643, 1, 
Table 4. Morphometrics of Rineloricaria laceolata $. \mathrm{n}=$ Number of specimens, $\mathrm{SD}=$ Standard deviation .

\begin{tabular}{|c|c|c|c|c|c|c|c|c|c|c|c|c|}
\hline \multirow{2}{*}{$\begin{array}{l}\text { Locality } \\
\text { Characters }\end{array}$} & \multicolumn{3}{|c|}{$\begin{array}{l}\text { Paraguay River basin } \\
(\mathrm{n}=51)\end{array}$} & \multicolumn{3}{|c|}{$\begin{array}{l}\text { upper rio Amazonas } \\
(\mathrm{n}=17)\end{array}$} & \multicolumn{3}{|c|}{$\begin{array}{l}\text { middle rio Amazonas and } \\
\text { tributaries }(n=26)\end{array}$} & \multicolumn{3}{|c|}{$\begin{array}{l}\text { rio Araguaia } \\
(\mathrm{n}=10)\end{array}$} \\
\hline & Range & Mean & SD & Range & Mean & SD & Range & Mean & SD & Range & Mean & SD \\
\hline \multicolumn{13}{|c|}{ Percents of standard length } \\
\hline Head length & 20.9-25.3 & 22.5 & 0.9 & $20.0-23.4$ & 21.4 & 0.8 & 20 & 22.5 & 1.3 & $20.2-22.5$ & 1.2 & 0.8 \\
\hline Predorsal length & 29.6-36.2 & 32.5 & 1.4 & 29.7-34.1 & 31.3 & 1.2 & 29.7-36.5 & 32.8 & 2.0 & 29.0-32.6 & 31.0 & 1.3 \\
\hline Postdorsal length & 63.9-71.1 & 68.0 & 1.5 & 66.1-71.7 & 69.3 & 1.4 & 64.4-71.1 & 67.9 & 1.9 & $67.6-71.4$ & 69.4 & 1.4 \\
\hline Prepectoral length & $16.6-21.4$ & 18.0 & 0.9 & 15.9 & 17.0 & 0.7 & $15.8-20.8$ & 17.9 & 1.2 & $16.1-18.0$ & 6.9 & 0.7 \\
\hline Postpectoral length & 80.8-85.8 & 83.3 & 1.2 & $81.1-$ & 85.0 & 1.3 & $81.6-88.2$ & 83.8 & 1.4 & 83.4-86.0 & 4.7 & 1.0 \\
\hline Prepelvic length & 28.9-36.1 & 32.3 & 1.6 & 28.4-33.4 & 30.8 & 1.4 & 29.4-36.9 & 32.3 & 2.1 & 29.4-33.0 & 31.1 & 1.3 \\
\hline Pospelvic length & $65.0-82.5$ & 69.3 & 3.6 & $67.2-$ & 70.1 & 1.3 & 64.3-71.4 & 68.4 & 2.1 & $66.8-71.7$ & 69.5 & 1.7 \\
\hline Preanal length & $30.5-49.0$ & 45.1 & 2.8 & $41.0-47.0$ & 43.4 & 1.7 & $40.0-50.6$ & 45.1 & 2.8 & $40.3-45.9$ & 43.4 & 2.1 \\
\hline Postanal length & $50.7-59.7$ & 54.8 & 1.8 & $53.3-58.3$ & 56.5 & 1.5 & 51.1-59.5 & 55.2 & 2.4 & $54.3-58.3$ & 56.5 & 1.5 \\
\hline Unbran & $17.1-25.8$ & 22.6 & 1.5 & $20.8-26.0$ & 23.5 & 1.6 & $19.7-26.9$ & 23.6 & 2.1 & 20.5-23.9 & 22.7 & 1.1 \\
\hline Unbran & $14.8-20.3$ & 17.1 & 1.1 & $14.4-18.4$ & 16.3 & 1.1 & $14.3-20.8$ & 17.5 & 1.6 & $15.7-17.6$ & 16.5 & 0.6 \\
\hline Unbra & 15.1-18.9 & 16.8 & 1.0 & 14.5-18.1 & 16 & 1.1 & $14.5-19.2$ & 17.0 & 1.2 & $15.7-17.1$ & 16.5 & 0.4 \\
\hline Unbr: & $8.0-2$ & 20.0 & 1.2 & $17.6-$ & 19 & 1.3 & $17.6-24.2$ & 20.8 & 1.5 & $17.5-20.3$ & 19.4 & 0.9 \\
\hline Supe & $32.6-59.8$ & 43.8 & 8.7 & $36.7-$ & 59.2 & 12.7 & $35.3-$ & 68.4 & 8.6 & 17.9-38.0 & 28.0 & 14.2 \\
\hline d_caudal_ffin ray & 13.8-20.9 & 17.6 & 2.0 & $16.4-27.7$ & 20 & 3.5 & $15.0-22.8$ & 18.3 & 2.3 & -18.9 & 16.9 & 1.1 \\
\hline Thora & $13.0-$ & 15.7 & 1.3 & 13. & 14.9 & 1.1 & 13.1 & 16.0 & 1.3 & -17.1 & 5.6 & 0.9 \\
\hline Abdo & 13.0 & 14.3 & 0.6 & 13. & 1 & .7 & 12.4 & 14.1 & 0.8 & -14.4 & 3.5 & 0.5 \\
\hline Cleith & 14.1 & 15.5 & 0.6 & 13 & 1 & 6 & 12.0 & 15.2 & 1.0 & 16.1 & 4.9 & 0.6 \\
\hline$e_{1}$ & & 9 & 0.8 & & & 0 & 8.6 & 10 & 1. & 1.3 & 10.1 & 0.7 \\
\hline Widtl & $9.1-13.7$ & 11.9 & 1.0 & $10.2-13.3$ & 11.7 & 0.8 & $9.3-14.3$ & 11.8 & 1.0 & $10.1-13.3$ & 11.7 & 1.0 \\
\hline Caudal $\mathrm{p}$ & $1.1-1.8$ & 1.5 & 0.1 & $1.3-1.6$ & 1. & 0.1 & $1.2-1.6$ & 1.4 & 0.1 & $1.3-1.6$ & 1.4 & 0.1 \\
\hline Caudal peduncle width & $2.5-4.2$ & 3.5 & 0.3 & $2.7-3.5$ & 3.1 & 0.2 & $2.7-3.9$ & 3.3 & 0.3 & 2.8-3.9 & 3.3 & 0.3 \\
\hline \multicolumn{13}{|c|}{ Percents of head length } \\
\hline Snout & $52.0-$ & 54.1 & 1.1 & 50.8-53.6 & 52.5 & 0.8 & 50.4 & 53.8 & 1.4 & 4.3 & 52.9 & 1.0 \\
\hline Eye diameter & $11.3-15.1$ & 13.1 & 1.1 & $11.6-1$ & 13.7 & 1.1 & $11.2-14.9$ & 13.1 & 1.1 & $12.5-16.3$ & 14.1 & 1.1 \\
\hline Maximum orbital diameter & 12.8-19.5 & 17.2 & 1.5 & 15.6-20.2 & 17.9 & 1.2 & $14.2-21.9$ & 17.7 & 2.3 & $17.1-20.7$ & 18.6 & 1.0 \\
\hline Interorbital width & 25.3-32.1 & 28.4 & 1.2 & 27.1-31.3 & 29.0 & 1.2 & 25.4-30.6 & 27.9 & 1.2 & 28.3-30.2 & 29.3 & 0.7 \\
\hline Internarial width & $6.6-11.7$ & 9.4 & 1.0 & 8.7-10.9 & 9.9 & 0.7 & 7.4-11.3 & 9.7 & 1.0 & $9.8-11.4$ & 10.5 & 0.5 \\
\hline Head depth & $36.0-46.2$ & 40.5 & 2.0 & $37.6-45.3$ & 41.0 & 2.0 & $36.9-43.5$ & 41.1 & 1.7 & 39.3-46.2 & 42.4 & 2.1 \\
\hline Head width & $57.7-70.4$ & 63.6 & 3.2 & 59.3-72.4 & 64.4 & 3.0 & $59.7-68.1$ & 63.8 & 2.2 & $62.0-66.4$ & 64.7 & 1.3 \\
\hline Free $n$ & $9.4-17.0$ & 12.3 & 2.0 & $8.0-14.4$ & 11.5 & 1.7 & $9.9-18.1$ & 13.3 & 2.9 & 9.3-13.8 & 11.4 & 1.3 \\
\hline Ventrorost & $3.4-5.4$ & 4.5 & 0.5 & $3.4-5.3$ & 4.4 & 0.5 & $3.6-5.6$ & 4.3 & 0.6 & $3.5-5.0$ & 4.3 & 0.4 \\
\hline Lower lip length & $13.2-22.7$ & 17.9 & 1.9 & 12.1-18.0 & 15.2 & 1.9 & $12.8-21.0$ & 17.6 & 1.7 & $14.0-17.9$ & 15.4 & 1.2 \\
\hline
\end{tabular}

(1), 86.5 mm SL, riacho Cancela, Nobres. NUP 5733, 1, (1), 71.0 mm SL, rio Cuiabá, Barão de Melgaço. NUP 5734, 1, 62.5 mm SL, rio Cuiabá, Barão de Melgaço. Mato Grosso do Sul State: MNRJ 21163, 1, 60.5 mm SL (discolored), rio Formoso, Bonito. MZUSP 43632, 4, 46.6-66.5 mm SL, riacho Betione, Miranda. MZUSP 59361, 15 of 32, (1), 42.2-73.6 mm SL, riacho at Chácara da Portela, Corguinho. MZUSP 59559, 15 of 31, (2), 50.6-73.7 mm SL, rio do Peixe, Rio Negro. MZUSP 59674, 1, 43.5 mm SL, Rio Novo, Aquidauana. MZUSP 59675, 3, 46.2-48.3 mm SL, córrego Água Clara, Arcinópolis. MZUSP 60006, 2, 37.1-45.8 mm SL, de córrego Ariranha, Aquidauana. MZUSP 85429, 1, 54.2 mm SL, riacho Nioaque, Guia Lopes da Laguna. NUP 2611, 1, 23.5 mm SL, rio Taquari, Ladário. ZUFMSPIS 1540, 1, 73.7 mm SL, riacho Salobrinha, Bodoquena. ZUFMSPIS 1547, 1, 78.7 mm SL, rio das Antas, Aquidauana. ZUFMS-PIS 1555, 1, 79.2 mm SL, riacho Salobrinha, Bodoquena. ZUFMS-PIS 1567, 1, 89.5 mm SL, riacho Salobrinha, Bodoquena. ZUFMS-PIS 1568, 2, 59.8-80.5 mm SL, riacho Salobrinha, Bodoquena. ZUFMSPIS 1821, 4, 28.1-77.5 mm SL, rio Coxim, São Gabriel do Oeste. ZUFMS-PIS 1830, 1, 70.5 mm SL, unspecified stream (affluent of the rio Coxim, Paraguay River basin), São Gabriel do Oeste. ZUFMSPIS 1893, 6, 21.3-56.9 mm SL, rio Coxim, São Gabriel do Oeste. ZUFMS-PIS 1919, 2, 51.1-76.2 mm SL, unspecified stream (affluent of the rio Coxim, Paraguay River basin), São Gabriel do Oeste. ZUFMS-PIS 1932, 8, 15.9-94.2 mm SL, rio Coxim, São Gabriel do Oeste. ZUFMS-PIS 1967, 5, 60.9-81.2 mm SL, unspecified stream (affluent of the rio Coxim, Paraguay River basin), São Gabriel do Oeste. Rondônia State: MNRJ 15604, 4, 50.6-66.4 mm SL, rio Boa Vista, Ouro Preto do Oeste. MNRJ 15667, 2, 44.3-55.6 mm SL (one estimated, caudal fin regenerated), rio Paineiras, Ouro Preto do Oeste. Tocantins State: MZUSP 52115, 18 + 2 c\&s of 52, (3), 40.0-83.4 mm SL, rio Água Fria, Araguaçu. Paraguay: Departamento de Amambay: MNHNP 376, 2, 43.0-48.0 mm SL, río Aquidabán, Parque Nacional Cerro Corá. MNHNP 521, 1, 20.0 mm SL, arroyo Aquidabán-niguí, Parque Nacional Cerro Corá. MNHNP 584, 1, 70.0 mm SL, arroyo Aquidabán-Niguí, Parque Nacional Cerro Corá. NRM 16156, 2, (2), 73.6-72.3 mm SL, arroyo Aquidabán-Niguí, Parque Nacional Cerro Corá. Departamento de Alto Paraguay: MNHNP 3640, 6, 17.0-78.8 mm SL, riacho Lechuza (lateral branch of the río Paraguay), city not specified. Departamento de Caaguazú: NRM 42040, 19, 19.4-86.0 mm SL, arroyo Guazú, Blas Garay. Departamento de Canindeyú: MNHNP 1213, 9, 44.0-73.0 mm SL, stream affluent of the río Jejuí-Mí, Curuguaty. MNHNP 1611, 3, 47.0-62.0 mm SL, stream affluent of the Río Jejuí-Mí, Curuguaty. MNHNP 3617, 1, 60.5 mm SL, río Jejuí-Mí, Reserva Natural del Bosque Mbaracayú. MNHNP 3631, 10, 54.2-88.1 mm SL, río Jejuí-Mí, Reserva Natural del Bosque Mbaracayú. MNHNP 3633, 2, 52.0-56.0 mm SL, arroyo Tacuara, Reserva Natural del Bosque Mbaracayú. MNHNP 3634, 2, 49.3-52.2 mm SL, río Jejuí-Mí, Reserva Natural del Bosque Mbaracayú. MNHNP 3640, 6, 17.0-78.8 mm SL, arroyo GuyraKehã, Reserva Natural del Bosque Mbaracayú. MNHNP 481, 2, 
47.0-58.0 mm SL, río Jejuí-mí, Curuguaty. NRM 32566, 17, (4), 42.8-82.6 mm SL, stream affluent of the río Jejuí-Mí, Curuguaty. UMMZ 206295, 19 of 33 (plus 1 ex. of R. aurata), (3), 45.6-95.0 mm SL, arroyo Carimbatay, Curuguaty. UMMZ 206526, 4 of 8, (2), 49.7-85.3 mm SL, unspecified stream (Paraguay River basin), Curuguaty. Departamento Central: ANSP 173128, 4 of 8, (4), 89.9104.6 mm SL, unspecified stream (Paraguay River basin), Itá. Departamento de Concepción: MNHNP 2350, 8, 43.9-81.0 mm SL, río Apa, San Carlos. Departamento de Cordillera: CZCEN 316, $2+4$ c\&s, (1), 71.5-98.1 mm SL, arroyo Piribebuy, Eusebio Ayala. NRM 32571, 1, (1), 77.4 mm SL, arroyo Piraretã, Colonia Piraretã. UMMZ 205688, 6, (2), 45.0-91.9 mm SL, arroyo Piribebuy, Eusebio Ayala. Departamento de Guairá: MNHNP 3661, 12, 21.0-62.3mm SL, stream affluent of the río Tebicuary-Mí, Colonia Natalicio Talavera. NRM 41898, 10, (4), 23.5-86.8 mm SL, stream affluent of the río Tebicuary-Mí, Colonia Natalicio Talavera. NRM 42066, 18, (4), 15.1-82.9 mm SL, arroyo Guazú, Independencia. NRM 42354, 31 (plus 6 ex. of $R$. aurata), 18.0-59.2 mm SL, arroyo Guazú, Independencia. NRM 45023, 3, 25.6-45.7 mm SL, arroyo Guazú, Independencia. Departamento de Itapúa: MNHNP 2699, 1, 49.2 mm SL, arroyo Capiibary (Paraná River basin), Trinidad. MNHNP 3485, 7, 32.5-69.1 mm SL, arroyo Tacuary (Paraguay River basin), San Pedro del Paraná. Departamento de Paraguarí: MNHNP 381, 20, 24.0-97.7 mm SL, arroyo Corrientes, Ybycuí. Departamento de Presidente Hayes: MNHNP 1831, 1, 62.0 mm SL, río Confuso at Estancia Golondrina. NRM 32567, 4, (2), 56.9-92.8 mm SL, río Confuso, Benjamín Aceval. Department de San Pedro: MNHNP 1216, 2, 62.0-68.0 mm SL, arroyo Aguaray-Mí, city not specified. NRM 16140, 4, (3), 70.6-86.2 mm SL, stream affluent of the río Aguaray, rio Verde. Departamento de Ñeembucú: CZCEN 321, 9, 33.0$84.3 \mathrm{~mm}$ SL, arroyo Yakare, Mburika. Peru: Departamento de Loreto: MUSM 17997, 6, (1), 41.0-81.5 mm SL, affluent of the río Pisqui, Parque Nacional Cordillera Azul. MUSM 18006, 10, (1), 46.3-96.0 mm SL, affluent of the río Pisqui, Parque Nacional Cordillera Azul. Departamento del Puno: MUSM 22479, 9 of 13, (5), 45.4-79.9 mm SL, arroyo La Cachuela, Tambopata. MUSM 25346, 9, (1), 33.0-89.7 mm SL, arroyo Gamitana, Tambopata. Departamento de San Martin: MUSM 9080, 4 + 1 c\&s, (5), 67.896.0 mm SL, río Pucayacu, Tarapoto. Departamento de Ucayali: MUSM 23025, 10 of 21, (6), 61.1-102.6 mm SL, río Shimbillo, Atalaya. MZUSP 26646, 1, (1), 88.6 mm SL, río Neshuya, Pucallpa. MZUSP 26752, 2 + 1 c\&s, (3), 87.0-97.1 mm SL, río Ucayali, Pucallpa.

\section{Rineloricaria parva (Boulenger, 1895) Figs. 11, 12 and 13}

Loricaria parva Boulenger, 1895: 527 [original description; type locality: Paraguay River, Descalvados, Mato Grosso State, Brazil]. -Boulenger, 1896: 32 [transcription of the original description; drawing of the body in lateral, dorsal and ventral views]. -Eigenmann et al., 1907: 121 [listed; Corumbá in Brazil, and near Asunción in Paraguay]. Eigenmann, 1909: 342 [listed; Paraguay River]. -Miranda Ribeiro, 1911: 125, fig. 68 [key to species; translation of the original description to Portuguese and reproduction of the figure of Boulenger, 1896]. -Miranda Ribeiro, 1912: 10 [listed; Paraguay River at Cáceres, Brazil]. -Fowler, 1932: 370 [drawing (inferior figure of page 364); description; upper Paraguay River in Brazil].
Loricaria Rhineloricaria [sic] parva. -Regan, 1904: 276 [listed; La Plata River basin; key of species; description]. -Eigenmann, 1910: 413 [listed; Paraguay River]. -Ringuelet et al., 1967: 410 [key of species; description; biological data; Paraná River in Argentina and Paraguay River in Brazil].

Rineloricaria parva. -Fowler, 1954: 119 [listed; Paraguay River]. -Isbrücker \& Nijssen, 1976: 111 [listed]. -Isbrücker, 1978: 112 [coments about generic status; lectotype designation: BMNH 1895.5.17.91). -Britski et al., 1999: 131 [listed; synopsis of the original description; drawing]. Chernoff et al., 2001: 146 [listed; Paraguay River in Paraguay]. -Rodriguez, 2001: 169, fig. 1-4 [sexual dimorphism; comparative pictures of male and female specimens; drawn of teeth]. -Ferraris, 2003: 343 [listed; Paraguay River in Argentina and Brazil]. -Vera \& Castillo, 2006: 56 [listed; Paraguay River in Paraguay]. -Britski et al., 2007: 160 [listed; synopsis of the original description; drawing]. -Ghazzi \& Oyakawa, 2007: 91 [listed; Paraguay River in Brazil].

Hemiloricaria parva. -Isbrücker et al., 2001: 23 [listed]. Isbrücker, 2001:27 [listed]. -López et al., 2003: 45 [listed; Paraná-Paraguay River basin]. -Menni, 2004: 81, 95 [listed; Paraná-Paraguay River basin]. -Ferraris, 2007: 246: [listed; Paraguay River in Argentina and Brazil].

Diagnosis. Rineloricaria parva is distinguished from most of its congeners by having four lateral plate series in longitudinal rows below the dorsal fin, the mid-dorsal series absent (Fig. 4a) [vs. five lateral plate series in longitudinal rows below the dorsal fin, the mid-dorsal series present and consisting in two to ten keeled plates situated below the dorsal series and beginning around insertion of the first dorsal-fin ray (Fig. 4b and 4c) in $R$. aequalicuspis, $R$. altipinnis, $R$. anhanguapitan, $R$. anitae, $R$. baliola, $R$. cacerensis, $R$. capitonia, $R$. caracasensis, $R$. daraha, $R$. eigenmanni, $R$. fallax, $R$. formosa, $R$. hasemani, $R$. heteroptera, $R$. isaaci, $R$. jaraguensis, $R$. jubata, $R$. konopickyi, $R$. kronei, $R$. latirostris, R. maacki, R. malabarbai, $R$. maquinensis, $R$. melini, $R$. microlepidogaster, $R$. morrowi, $R$. osvaldoi, $R$. pentamaculata, $R$. phoxocephala, $R$. platyura, $R$. reisi, $R$. rupestris, $R$. steindachneri, $R$. stewarti, $R$. teffeana, $R$. tropeira, and $R$. zaina]. It is distinguished from remaining members of the genus, except $R$. castroi and $R$. wolfei, by presenting the caudal fin with both unbranched rays extended as long filaments (Fig. 11) [vs. caudal fin with both unbranched rays not prolonged as filaments or with only the superior unbranched ray extended as a filament in $R$. aurata, $R$. beni, $R$. cadeae, $R$. catamarcensis, $R$. felipponei, $R$. lanceolata, $R$. langei, $R$. lima, $R$. longicauda, $R$. magdalenae, $R$. misionera, $R$. nigricauda, $R$. pareiacantha, $R$. quadrensis, $R$. sanga, $R$. setepovos, $R$. sneiderni, $R$. stellata, $R$. strigilata, $R$. thrissoceps, and $R$. uracantha]. It is distinguished from $R$. castroi and $R$. wolfei by having the tip of the snout rounded in a dorsal view; three longitudinal series of abdominal plates on the median complex; and the tip of the snout with a wide and long area of naked skin without odontodes at the rostral plate, which is 
extended laterally and surpass the sensorial pore ventrally exposed of the infraorbital 1 [vs. tip of the snout pointed; five to seven longitudinal series of abdominal plates on the median complex; tip of the snout with a narrow and short area of naked skin at the rostral plate, which does not surpass the sensorial pore ventrally exposed of the infraorbital 1].
Description. Morphometric data presented in Table 5. Snout tip straight in lateral view, not raised. Dorsal profile from snout tip to frontals straight, elevated from this point to nuchal plate, declined from dorsal-fin origin to penultimate dorsal plate, elevated from last dorsal plate to posterior end of caudal fin. Ventral profile from snout tip to anal-fin base convex,
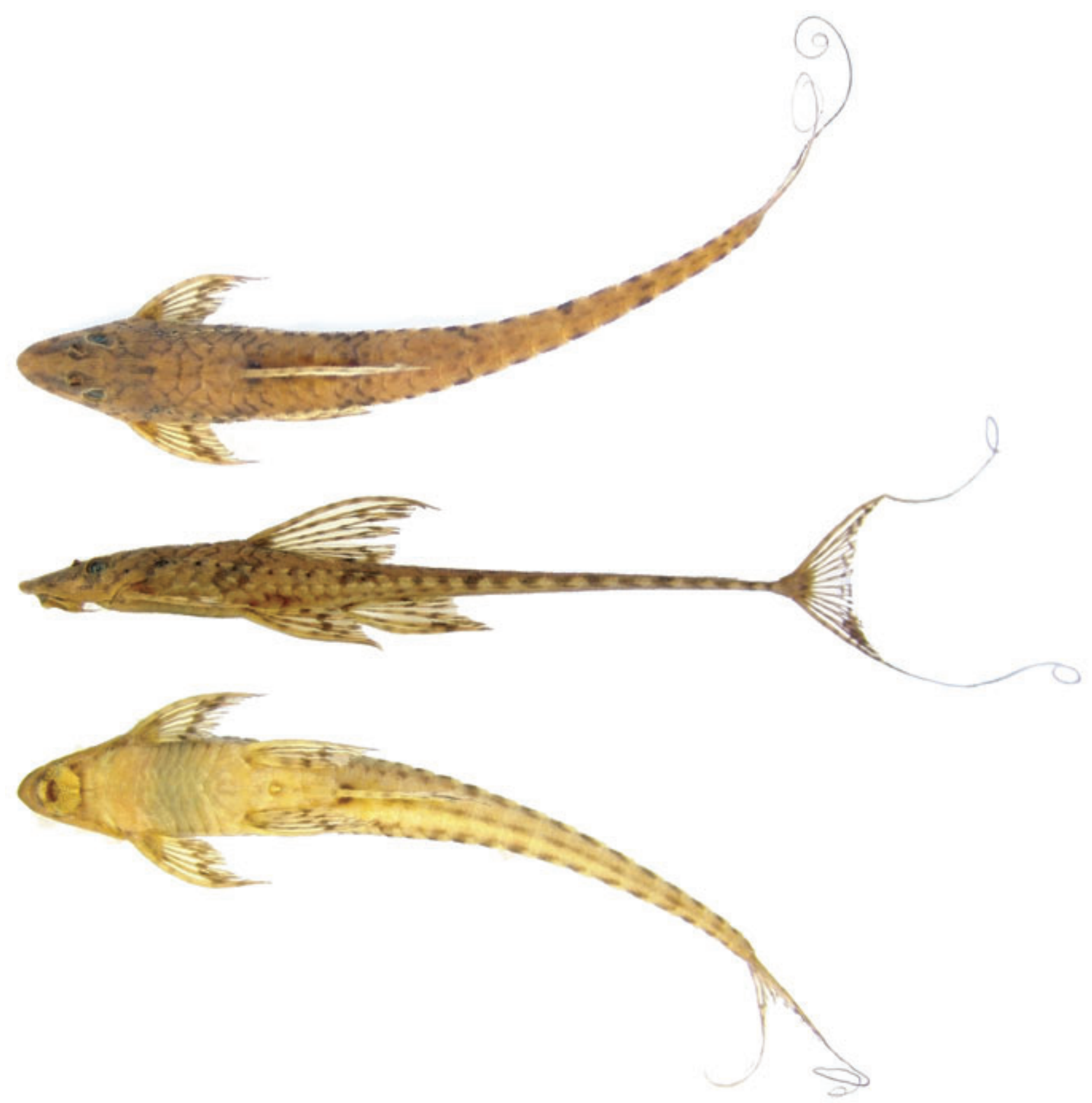

Fig. 11. Rineloricaria parva, NRM 37673, 86.3 mm SL, Paraguay River, Bahía Negra, Departamento de Presidente Hayes, Paraguay. 


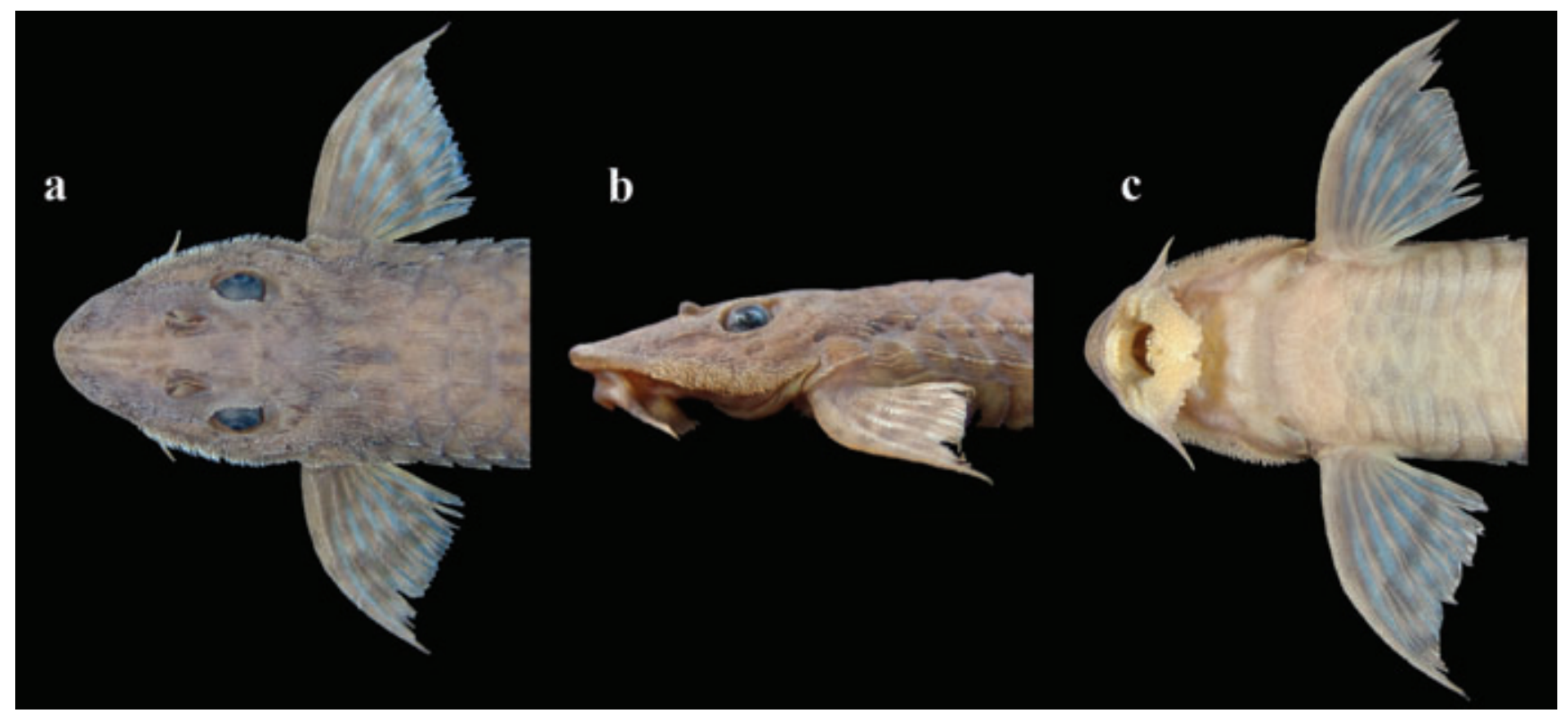

Fig. 12. Hypetrophied odontodes developed in breeding male specimens of Rineloricaria parva, ZUFMS-PIS 567, 94.3 mm SL: a) dorsal view, b) lateral view, c) ventral view.

straight from that point to penultimate ventral plate, declined from last ventral plate to end of caudal fin.

Snout tip rounded in dorsal view, lateral margins of head straight. Odontodes of head and trunk small, thick, aligned forming striae, more evident between nostrils and on region posterior to eyes. Infraorbital series with six bones, infraorbital 1 with a sensorial pore exposed ventrally, infraorbitals 2,3 , and 4 convexly raised from anterior portion of snout to eye. Rostral plate with an area of naked skin without odontodes at tip of the snout, wide and long, laterally extended, surpassing the sensorial pore ventrally exposed of infraorbital 1 and reaching horizontal line through margin of upper lip. Posterior margin of parieto-supraoccipital concave, sometimes pointed with lateral margins convex. Parieto-supraoccipital and predorsal plates smooth, without ridges, or with ridges very low. First three lateral plates of dorsal series with moderatelydeveloped ridges or keels. Superior margin of orbit low or slightly raised, postorbital notch small to medium. Eye large, rounded to slightly oval horizontally, iris rounded, olive, pupil vertically oval, black.

Lower lip narrow, ventral surface covered by short papillae with rounded tip; papillae slightly bigger at line bordering upper lip and close to dentary. Lower lip margins with very short fringes (Fig. 12c); upper lip margin with shorter fringes. Maxillary barbel long, longer than orbital diameter, surpassing distal margin of lower lip and almost reaching ventral border of the subocular cheek plate 1 . Teeth bicuspid, long, mesial cusp greater and wider than lateral, dentary teeth larger than premaxillary. Premaxilla with 7(4), 8(33), 9(15), 10(14), or 11(1) teeth; dentary with 7(4), 8(28), 9(24), or 10(16) teeth. Sexual dimorphism on teeth present (see sexual dimorphism). Branchiostegal rays 4(7).
Body narrow and long, four lateral plate series in longitudinal rows below dorsal fin: dorsal, median, mid-ventral, and ventral; mid-dorsal series absent. Median and mid-ventral series with rough well-developed keels; last plate of mid-ventral series extended around end of anal fin. Median series bearing sensory canal between two proximate keels on caudal

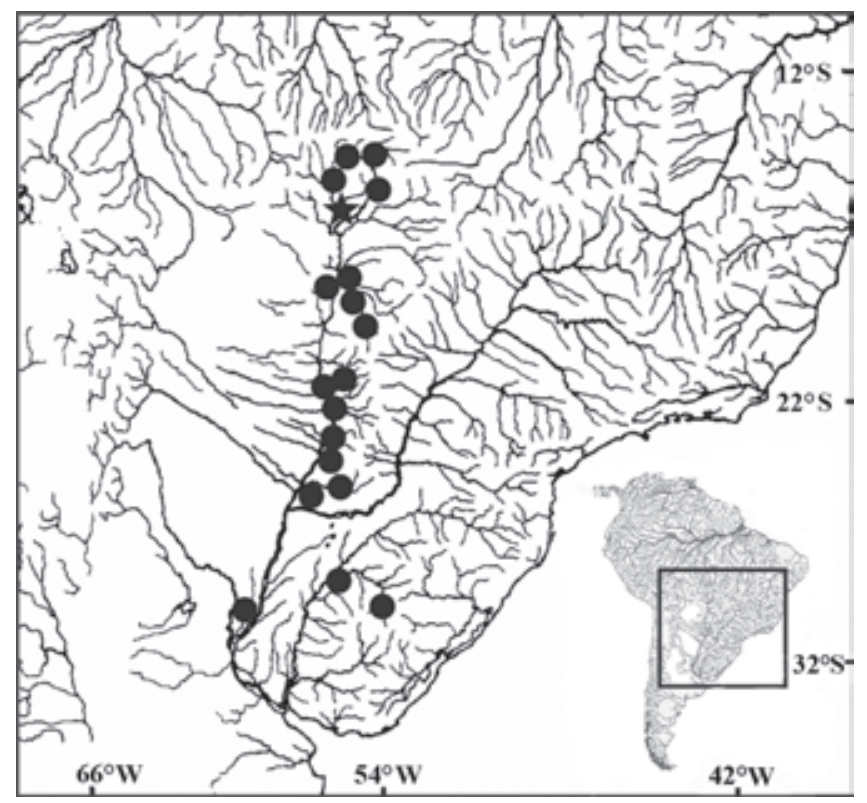

Fig. 13. Partial map of South America showing the geographical distribution of Rineloricaria parva. Dots = Occurrence, Star = Type locality (Descalvados, Mato Grosso State, Brazil). 
Table 5. Morphometrics of Rineloricaria parva. $\mathrm{n}$ = Number of specimens, SD = Standard deviation.

\begin{tabular}{|c|c|c|c|c|c|c|c|c|}
\hline \multirow{2}{*}{$\frac{\text { Locality }}{\text { Characters }}$} & \multicolumn{3}{|c|}{$\begin{array}{c}\text { rio Paraguay } \\
(\mathrm{n}=64)\end{array}$} & \multicolumn{2}{|c|}{$\begin{array}{c}\text { rio Paraná } \\
(\mathrm{n}=3)\end{array}$} & \multicolumn{3}{|c|}{$\begin{array}{c}\text { rio Uruguay } \\
(\mathrm{n}=10)\end{array}$} \\
\hline & Range & Mean & SD & Range & Mean & Range & Mean & SD \\
\hline Standard length (mm) & $69.8-120.0$ & 86.4 & 11.7 & 76.1-85.9 & 82.1 & $74.0-118.4$ & 94.4 & 15.8 \\
\hline \multicolumn{9}{|c|}{ Percents of standard length } \\
\hline Head length & 18.3-22.0 & 19.9 & 0.8 & 19.1-19.3 & 19.2 & $18.2-20.1$ & 19.1 & 0.6 \\
\hline Predorsal length & 20.7-31.3 & 28.8 & 1.4 & 27.6-28.9 & 28.1 & 27.3-30.3 & 28.0 & 0.9 \\
\hline Postdorsal length & 69.1-73.2 & 71.4 & 1.1 & 71.9-72.3 & 72.0 & $69.8-72.9$ & 72.0 & 0.9 \\
\hline Prepectoral length & 14.9-17.9 & 16.2 & 0.7 & $15.2-15.6$ & 15.4 & $14.1-16.3$ & 15.4 & 0.7 \\
\hline Postpectoral length & $82.3-87.2$ & 85.1 & 1.2 & 84.4-85.9 & 85.4 & $84.2-86.9$ & 85.7 & 0.7 \\
\hline Prepelvic length & $26.8-32.2$ & 29.0 & 1.3 & $27.7-28.5$ & 28.2 & $27.4-31.3$ & 28.5 & 1.1 \\
\hline Pospelvic length & 68.1-85.5 & 71.8 & 2.7 & $71.8-73.0$ & 72.2 & $68.5-73.0$ & 71.9 & 1.4 \\
\hline Preanal length & $38.7-44.7$ & 41.0 & 1.6 & $38.9-40.4$ & 39.8 & $38.9-44.0$ & 40.2 & 1.5 \\
\hline Posanal length & 55.1-61.8 & 59.0 & 1.4 & $59.5-60.5$ & 59.9 & $55.9-61.0$ & 59.5 & 1.4 \\
\hline Unbranched dorsal-fin ray & 18.4-32.4 & 25.3 & 2.0 & $23.1-24.2$ & 23.7 & $22.1-24.7$ & 23.3 & 0.9 \\
\hline Unbranched pectoral-fin ray & 15.4-21.6 & 18.2 & 1.2 & $16.4-17.0$ & 16.6 & 14.8-18.2 & 16.4 & 1.0 \\
\hline Unbranched pelvic-fin ray & 14.9-19.3 & 16.9 & 1.0 & 15.4-16.3 & 15.9 & $14.0-18.0$ & 15.6 & 1.0 \\
\hline Unbranched anal-fin ray & $15.7-23.3$ & 19.4 & 1.4 & $17.6-18.0$ & 17.8 & 16.8-18.3 & 17.6 & 0.6 \\
\hline Superior unbranched caudal-fin ray & 38.3-80.0 & 62.0 & 15.7 & - & - & $21.2-48.7$ & 32.4 & 12.4 \\
\hline Inferior unbranched caudal-fin ray & 41.3-64.9 & 46.3 & 10.4 & - & - & 18.1-26.9 & 22.1 & 4.5 \\
\hline Thoracic lenght & 12.4-17.0 & 14.3 & 1.0 & $13.7-15.2$ & 14.2 & 13.4-16.6 & 14.4 & 0.9 \\
\hline Abdominal lenght & $11.8-16.2$ & 13.1 & 0.7 & $12.8-13.0$ & 12.9 & $12.0-14.1$ & 13.0 & 0.9 \\
\hline Cleithral width & 12.4-16.0 & 13.8 & 0.7 & 12.9-13.6 & 13.2 & $12.4-14.8$ & 13.1 & 0.7 \\
\hline Depth at dorsal-fin origin & $8.0-11.1$ & 9.3 & 0.7 & $7.5-8.0$ & 7.8 & $7.7-10.0$ & 8.7 & 0.7 \\
\hline Width at anal-fin origin & $9.1-12.5$ & 10.6 & 0.8 & $9.1-9.5$ & 9.3 & $9.2-10.8$ & 9.9 & 0.5 \\
\hline Caudal peduncle depth & $0.9-1.5$ & 1.2 & 0.1 & $1.0-1.1$ & 1.0 & $1.1-1.4$ & 1.2 & 0.1 \\
\hline Caudal peduncle width & $2.4-3.8$ & 3.1 & 0.3 & $2.5-2.6$ & 2.6 & 2.6-3.1 & 2.8 & 0.1 \\
\hline \multicolumn{9}{|c|}{ Percents of head length } \\
\hline Snout length & 49.6-54.5 & 52.1 & 1.1 & 47.9-52.2 & 50.2 & 49.6-52.1 & 50.8 & 1.0 \\
\hline Eye diameter & 14.6-18.4 & 16.6 & 0.9 & 16.3-17.4 & 17.0 & 13.9-17.4 & 15.6 & 1.1 \\
\hline Maximum orbital diameter & $20.5-27.0$ & 23.5 & 1.3 & 22.9-24.5 & 23.7 & 21.3-26.1 & 22.6 & 1.5 \\
\hline Interorbital width & 26.3-32.0 & 29.3 & 1.3 & 27.6-28.1 & 27.9 & 26.2-28.1 & 27.1 & 0.5 \\
\hline Internarial width & 7.9-11.0 & 9.5 & 0.7 & 8.0-9.5 & 9.0 & 8.1-10.5 & 8.9 & 0.7 \\
\hline Head depth & $35.0-64.5$ & 40.6 & 3.7 & $36.7-39.3$ & 38.4 & 37.6-41.6 & 40.3 & 1.3 \\
\hline Head width & 59.1-71.9 & 64.5 & 2.5 & $60.4-61.3$ & 60.9 & 61.3-68.0 & 63.6 & 2.2 \\
\hline Free maxillary barbel & $13.0-20.6$ & 16.1 & 1.7 & 13.2 & - & $11.3-18.0$ & 13.8 & 2.5 \\
\hline Ventrorostral length & $5.4-8.9$ & 7.2 & 0.8 & $6.9-8.6$ & 8.0 & $6.4-8.0$ & 7.4 & 0.5 \\
\hline Lower lip length & $10.7-16.3$ & 14.1 & 1.2 & 13.1 & - & 10.9-15.9 & 12.4 & 1.5 \\
\hline
\end{tabular}

peduncle. Longitudinal lateral plates 29(14), 30(48), 31(13), or 32(2); posterior plates of median series 15(21), 16(50), or 17(6). Lateral line complete. Lateral abdominal plates 5(17), 6(32), $7(24)$, or 8(4); borders of plates in contact with lateral plates of mid-ventral series. Lateral region of body posterior to pectoral-fin insertion with a slender area of naked skin between borders of lateral plates of mid-ventral series and of lateral abdominal plates, narrower than caudal peduncle width. Abdominal plates of posterior complex with a large welldefined preanal plate bordered by three plates and these by five plates, sometimes divided in smaller plates. Abdominal plates of median complex parallel and longitudinally arranged in three series. Abdominal plates of anterior complex irregular, smaller than other plates, not projected toward lip; anterior margin convex, slightly surpassing horizontal line of anterior margin of cleithrum exposed ventrally. Vertebrae 25(1), 26(7), or 27(1); ribs 4(9).

Dorsal fin ii,6(2); ii,7(74); or ii,8(1); dorsal-fin spinelet present, locking mechanism not functional; unbranched ray conspicuously longer than branched rays, depressed unbranched ray reaching eight plate posterior to its base, last branched ray reaching fourth plate; distal margin truncate. Pectoral fin i,6(77); unbranched ray conspicuously longer than branched rays, depressed unbranched ray reaching almost half pelvic-fin length; distal margin truncate. Pelvic fin i,5(77); unbranched ray evidently longer than branched rays, depressed unbranched ray and two following branched rays reaching beyond anal-fin origin; distal margin truncate. Anal fin i,5(77); unbranched ray evidently longer than branched rays, depressed unbranched ray reaching sixth plate posterior to its base; depressed last branched ray reaching fourth plate; distal margin truncate. Caudal fin emarginated, i,9,i(1) or $\mathrm{i}, 10, \mathrm{i}(74)$; superior and inferior unbranched rays extended as long filaments similar in length to each other.

Color in alcohol. Dorsal surface of body light to dark brown overall ground coloration, ventral surface yellowish brown, ventral plates posterior to pelvic fin with dark brown blotches. Dorsal surface of head from anterior margin of snout to eyes with two longitudinal dark brown stripes. Lateral margins of head from infraorbital 4 to subocular cheek plate 1 with a transversal dark brown band; irregular dark brown blotches on postrostral plates, subocular cheek plates 1 and 2, opercle, and cleithrum. Sphenotic and parieto-supraoccipital with narrow dark brown stripe. Pores of sensorial canal of head and predorsal region highlighted by black pigments. Dorsal 
surface of upper and lower lip with two longitudinal dark brown stripes. Dorsal surface of trunk with six transversal dark brown bands; first band at base of origin of first rays of dorsal fin, oblique, extending toward last pectoral-fin ray; second just behind dorsal-fin base; following bands similar, equidistantly separated. Some specimens about $50 \mathrm{~mm}$ SL with a narrow and inconspicuous band on parietosupraoccipital. All fin rays light brown with dark brown stripes. Pectoral, pelvic, dorsal, and anal fins with dark brown blotches on distal portion of rays, forming narrow transversal stripe not reaching fin margin; caudal-fin base with narrow dark brown spot, distal region with dark brown transversal stripe. Caudal fin of specimens about $45 \mathrm{~mm}$ SL with large transversal distal band from middle of rays to distal margin; specimens about 60-75 mm SL with moderately large transversal dark brown band on its distal margin; specimens about $80 \mathrm{~mm} \mathrm{SL}$ with narrower, distal, transverse, dark brown band.

Sexual dimorphism. Dissected females with mature oocytes at about $93 \mathrm{~mm}$ SL. Males showing sexually dimorphic odontodes at about $80 \mathrm{~mm}$ SL. Breeding male specimens with premaxillary and dentary teeth having its mesial cusp enlarged and rounded. Arrangement and form of dimorphic odontodes different from those described to Rineloricaria aurata and $R$. lanceolata in the anterior section, to $R$. fallax on Steindachner (1915), and to R. heteroptera in Isbrücker \& Nijssen (1976). Breeding male specimens with dimorphic odontodes arranged on lateral margins of head and on dorsal surface of pectoral-fin rays, absent on dorsum of head and predorsal plates (Fig. 12). Dimorphic odontodes on lateral margin of head short, not covered by skin, tips hook-like curved, distributed in an area much narrower than those in $R$. aurata and $R$. lanceolata over postrostral plates 2, 3, 4, subocular cheek plates 1,2 , and opercle, lacking on suprarostral plates. Dimorphic odontodes on dorsal region of pectoral branched rays short, curved medially, covered by skin at base, distributed over almost entire portion of first to fifth branched rays; dimorphic odontodes on unbranched ray slightly shorter and more densely arranged.

Distribution and habitat. Rineloricaria parva is distributed in the Paraguay River basin in Brazil and Paraguay, Paraná River in Argentina, and Uruguay River in Brazil (Fig. 13). Additional records of $R$. parva from Rodriguez (2003) indicated that this species is distributed along the whole Paraná River in Argentina (from region of Esteros del Iberá in Provincia de Corrientes to the mouth of the Paraná River in Provincia de Buenos Aires) and the Uruguay River in Argentina (a single record from Concordia, Provincia de Entre Ríos). Therefore, its distribution encompasses the main rivers of the La Plata River basin, except Paraná River upstream from the Yacyretá Hydroelectric Dam and the upper Paraná River in Brazil. In Paraguay, specimens of $R$. parva were captured in the Paraguay River margins associated to floating macrophyte banks. Most specimens examined in this revision were collected in large rivers but seem to have been poorly sampled in streams. Heckman (1998) cited this species in the Brazilian Pantanal where it is abundant in roots of floating macrophytes (usually plants of the genus Salvinia).

Examined material. Type specimens: BMNH 1895.5.17.91, photograph of lectotype, Descalvados, Mato Grosso, Brazil. Nontype specimens: Argentina: Provincia de Santa Fé: MCP 40426, 13 of 23, (3), 61.5-86.5 mm SL, rio Paraná, Santa Fé. Brazil: Mato Grosso State: MCP 15703, 5, (2), 60.0-95.6 mm SL, rio Paraguai, Cáceres. MCP 15728, 1 of 2, (1), 76.7 mm SL, rio Bugres, Barra do Bugres. MCP 36517, 1, 86.4 mm SL, stream of the Poconé Pantanal, Poconé. MCP 36518, 9, 45.1-58.3 mm SL, unspecified stream (Paraguay River basin), Poconé. MCP 36519, 1, (1), 75.8 mm SL, riacho Caramujo, Cáceres. MCP 40425, 2, 67.0-67.8 mm SL, pool at the Poconé Pantanal, Poconé. MNRJ 21861, 2, 41.1-47.1 mm SL, locality not specified (Paraguay River basin), Poconé. MZUEL 3518, 45, 45.5$67.1 \mathrm{~mm}$ SL, stream affluent of the rio Pixaim, Poconé. MZUEL 5020, 12, (6), 84.0-96.9 mm SL, stream affluent of the rio Pixaim, Poconé. MZUEL 5157, 3, 31.3-48.5 mm SL, pond near rio Corixo, Poconé. MZUEL 5160, 1, $94.1 \mathrm{~mm}$ SL, stream affluent of the rio Pixaim, Poconé. MZUEL 5161, 14, 33.6-88.8 mm SL, stream near rio Pixaim, Poconé. MZUSP 19253, 1, (1), 86.6 mm SL, locality not specified (Paraguay River basin), Poconé. MZUSP 44410, 7, (1), 48.0-69.9 mm SL, rio Paraguai, Cáceres. MZUSP 44428, 1, 63.4 mm SL, riacho Caramujo, Cáceres. NUP 3427, 3, (2), 75.6-82.1 mm SL, baía Sinhá Mariana, Barão de Melgaço. NUP 4144, 1, (1), 71.5 mm SL, baía Sinhá Mariana, Barão de Melgaço. NUP 4365, 14, 54.1-80.1 mm SL, baía Caiçaras, Cáceres. NUP 4416, 4, (3), 57.2-73.9 mm SL, córrego Cancela, Nobres. NUP 4646, 3, (1), 65.50-85.70 mm SL, baía Sinhá Mariana (Paraguay River basin), Barão de Melgaço. NUP 4647, 2, (1), 58.2-78.0 mm SL, baía Sinhá Mariana, Barão de Melgaço. NUP 4648, 2, 58.9-64.8 mm SL, baía Sinhá Mariana, Barão de Melgaço. NUP 4649, 1 c\&s, 64.8 mm SL, baía Sinhá Mariana, Barão de Melgaço. NUP 4650, 3, 56.9-71.7 mm SL, baía Sinhá Mariana, Barão de Melgaço. NUP 4651, 4, (1), 63.3-79.7 mm SL, baía Sinhá Mariana, Barão de Melgaço. NUP 4652, 4, (1), 63.1-75.0 mm SL, baía Sinhá Mariana, Barão de Melgaço. NUP 6121, 1 c\&s, 88.3 mm SL, baía Sinhá Mariana, Barão de Melgaço. Mato Grosso do Sul State: DZSJRP 2270, 21, 57.44-98.55 mm SL (1 specimen with the caudal fin regenerated), rio Miranda, Miranda. MZUEL 5152, 2, 96.4-111.3 mm SL, stream affluent of the rio Miranda, Corumbá. MZUEL 5153, 2, 58.3-64.7 mm SL, riacho Passo da Lontra, Corumbá. MZUEL 5155, 1, 85.1 mm SL, baía da Medalha in rio Miranda, Corumbá. MZUEL 5156, 1, 79.4 mm SL, Porto da Manga at rio Paraguai, Corumbá. MZUSP 36329, 3, (1), 64.0-96.0 mm SL (1 specimen with the caudal fin regenerated), Santa Branca Farm, Nhecolandia. MZUSP 49957, 1, 98.8 mm SL, baía Albuquerque, Corumbá. MZUSP 59350, 6 (plus 6 ex. of R. aurata), 53.1-68.7 mm SL, riacho Santo Antônio, Aquidauana. MZUSP 59368, 1 (plus 1 ex. of R. aurata), 69.8 mm SL, rio Abobral 3, Corumbá. MZUSP 59369, 1 (plus 1 ex. of R. aurata), 46.3 mm SL, rio do Peixe, Corumbá. MZUSP 60010, 20 of 46, (1), 45.2-80.7 mm SL, rio Vermelho, Corumbá. NUP 202, 8, (4), 81.85-94.0 mm SL, rio Paraguai, Corumbá. NUP 4759, 6, 74.9-79.8 mm SL, channel at Transpantaneira road, Corumbá. NUP 6120, 1 c\&s, 86.1 mm SL, rio Paraguai, Corumbá. ZUFMS-PIS 567, 2, 77.1-94.3 mm SL, Paraguay River, Corumbá. ZUFMS-PIS 656, 1 (plus 8 ex. of $R$. aurata), 64.9 mm SL, baía das Antas, Corumbá. ZUFMS-PIS 673, 1, 91.0 mm SL, rio Miranda, Corumbá. ZUFMS-PIS 695, 15, 60.5-93.3 mm SL, marginal pond at MS 325 Road, Corumbá. ZUFMS-PIS 698, 2, 64.289.3 mm SL, marginal pond at MS 325 road, Corumbá. ZUFMS-PIS 700, 1, 83.0 mm SL, lago do Jacadigo, Corumbá. ZUFMS-PIS 704, 1, 79.1 mm SL, baía Grande, Corumbá. ZUFMS-PIS 826, 1, 59.2 mm SL, 
lago do Cervo, Corumbá. Rio Grande do Sul State: MCP 16304, 3 + 1 c\&s, (3), 69.3-117.3 mm SL, rio Santa Maria, Rosário Sul. MCP 19588, 2, (2), 84.5-104.7 mm SL, rio Santa Maria, Rosário Sul. MCP 22841, 1, (1), 76.2 mm SL, arroio Ximbocuzinho, São Luiz Gonzaga. MCP 22843, 4 + 2 c\&s, (4), 63.8-97.6 mm SL, rio Uruguay, Uruguaiana. UFRGS 7706, 1, 96.6 mm SL, rio Santa Maria, Rosário Sul. UFRGS 8531, 2, 66.4-76.4 mm SL, arroio do Salso, Rosário Sul. Paraguay: Departamento de Alto Paraguay: MNHNP 1355, 5, 81.0-82.1 mm SL, río Paraguay, Bahía Negra. MNHNP 1581, 2, 58.5-66.0 mm SL, río Paraguay, Bahía Negra. MNHNP 2343, 11, 46.0-85.2 mm SL, río Paraguay, Puerto Voluntad. MNHNP 3582, 2, 61.0-65.0 mm SL, MNHNP 3671, 1 + 2 c\&s, 61.7-97.9 mm SL, río Paraguay, Puerto Esperanza. MNHNP 3672, 1 c\&s, 83.2 mm SL, río Paraguay, Puerto Boquerón. MZUSP 54224, 1, 71.6 mm SL, río Paraguay, Puerto Lidia. MZUSP 54227, 1, (1), $57.4 \mathrm{~mm}$ SL, riacho Celina (lateral branch of the río Paraguay), city not specified. NRM 33313, 30 (plus 1 ex. of $R$. aurata), (4), 49.1-88.4 mm SL, río Paraguay, Bahía Negra. NRM 37673, 11 (plus 2 ex. of $R$. aurata), (4), 56.8-86.3 mm SL, río Paraguay, Bahía Negra. Departamento Central: CZCEN 237, 3, 68.3-75.3 mm SL, río Paraguay, Asunción. CZCEN 318, 11, 53.1-88.0 mm SL, río Paraguay, Limpio. CZCEN 319, 1, 61.9 mm SL, río Paraguay, Limpio. MNHNP 1911, 1, 92.0 mm SL, río Salado, Limpio. MNRJ 24315, 1, 80.0 mm SL (estimated, caudal fin regenerated), río Salado, Limpio. MNRJ 24316, 3, (2), 65.6-87.5 mm SL, río Salado, Limpio. NRM 41952, 1, (1), $86.3 \mathrm{~mm}$ SL, dike associated to the lagoYpacaraí, Areguá. NRM 45208, 15, (8), 63.3-119.3 mm SL, río Paray, Buey Rodeo. NRM 45303, 2, (2), 75.7-75.8 mm SL, río Salado, Limpio. Departamento de Concepción: MNHNP 2748, 10, 67.0-94.2 mm SL, río Paraguay, Concepción. MNHNP 3663, 6, 84.0-98.2 mm SL, arroyo Laguna Penayo, Paso Barreto. NRM 23028, 11 (plus 1 ex. of $R$. aurata), (6), 79.0-112.0 mm SL, arroyo Laguna Penayo, Paso Barreto. Departamento de Cordillera: MNHNP 377, 1, 58.5 mm SL, swamp associated to the lago Ypacaraí, San Bernardino. Departamento de Misiones: MNHNP 1841, 6, 64.0-135.2 mm SL, río Tebicuary, Villa Florida. MNHNP 3311, 2, 78.0-90.0 mm SL, río Tebicuary, Villa Florida. Departamento de Ñeembucú: CZCEN 320, 3, 37.0-45.0 mm SL, arroyo Yacaré, Mburika. MNHNP1409, 1, 40.0 mm SL, Arroyo Paso Cornélio, Humaitá. MNHNP 2574, 4, 43.1-48.0 mm SL, arroyo Paso Cornélio, Humaitá. NRM 32827, 4, 45.3-58.1 mm SL, swamp associated to the arroyo Paso Cornélio, Humaitá. Departamento de Paraguarí: ANSP 175151, 2, (2), 85.6-105.3 mm SL, río Tebicuary, Caapucú. UMMZ 206043, 3, (1), 54.8-109.6 mm SL (discolored), arroyo Mbaey, Paraguarí. Departamento de Presidente Hayes: ANSP 175157, 2, 52.4-70.7 mm SL, pool associated to the río Paraguay, Mariano Roque Alonso. MNHNP 1555, 1, 105.2 mm SL, riacho Siete Puntas (lateral branch of the Río Paraguay), Villa San Jorge. NRM 43371, 1, (1), 86.9 mm SL, riacho Siete Puntas (lateral branch of the río Paraguay), Villa San Jorge. NRM 44377, 9, (2), 66.7-92.1 mm SL, riacho Siete Puntas (lateral branch of the río Paraguay), Villa San Jorge. Departamento de San Pedro: NRM 44455, 2, (2), 75.4-96.4 mm SL, río Paraguay, San Pedro del Ycuamandiyú.

\section{Key to the species of Rineloricaria from the Paraguay River basin}

1a. Five lateral plate series in longitudinal rows below the dorsal fin, composed by the dorsal, mid-dorsal, median, mid-ventral, and ventral series (Fig. 4c); abdominal plates of anterior complex projected toward lip, surpassing horizontal line around pectoral-fin insertion . Rineloricaria cacerensis 1b. Four lateral plate series in longitudinal rows below the dorsal fin, the mid-dorsal plate series absent (Fig. 4a); abdominal plates of anterior complex not projected toward lip, ending just about horizontal line around pectoral-fin insertion .. 2

2a. Lateral region of the body just posterior to the pectoralfin insertion with a slender area of naked skin, narrower than the caudal peduncle width (Fig. 4b and 4c); tip of the snout with a wide naked area without odontodes on the rostral plate, which is extended laterally and surpass the sensorial pore ventrally exposed of the infraorbital 1 ; pectoral, dorsal, pelvic, and anal fins with the unbranched ray conspicuously longer than the branched rays; breeding male specimens with short hypertrophied sexually dimorphic odontodes developed only on the sides of the head and on dorsum of the pectoral fin, not developed on the dorsum of the head and predorsal plates (Fig. 12) Rineloricaria parva

2b. Lateral region of the body just posterior to the pectoralfin insertion with a broad area of naked skin, similar in thickness to the caudal peduncle width (Fig. 4a); tip of the snout with a narrow and short naked area without odontodes on the rostral plate, which does not surpass the sensorial pore ventrally exposed of the infraorbital 1 ; dorsal, pectoral, pelvic, and anal fins with the unbranched ray not much longer than the branched rays; breeding male specimens with long hypertrophied sexually dimorphic odontodes developed on the sides of the head, dorsum of the head and predorsal plates, and dorsum of the pectoral fin(Figs. 3 and 8 ) ........................................ 3

3a. Dorsum of the head rough, with pronounced ridges from nasal plates to the interorbital region; pectoral and dorsal fins with irregular dark stripes over rays, a dark spot on base of first branched rays and another distally, caudal fin with a transversal dark band on distal region; tip of the snout pointed in a dorsal view ......... Rineloricaria aurata 3b. Dorsum of the head slightly rough, without ridges between nostrils and interorbital region; pectoral, dorsal, and caudal fins with a broad longitudinal dark band running parallel to the first rays; tip of the snout rounded in a dorsal view Rineloricaria lanceolata

\section{Discussion}

Rineloricaria aurata was only known from the holotype. The species was described by Knaack (2003) based on three specimens captured in the Aquidabán River, Paraguay. Those specimens were collected in an expedition for aquarium trade, kept alive, and exported to Germany. The author preserved only one exemplar as the type specimen (ZMA 123591, holotype, Fig. 6); the other two specimens were kept alive for reproduction purposes and were not deposited in a museum. In the original description the author did not present a diagnosis for this species but mentioned in the abstract that a uniquely colored mailed catfish is described. A description of the coloration of the holotype is on the Remarks section of the $R$. aurata 
description; see above. During this revision we have examined numerous museum records from the Paraguay River basin in Paraguay that revealed no specimen with the same color pattern, including material from the type locality and other localities of the Aquidabán River basin. We conclude that the specimens used in the original description are anomalous, perhaps xanthic forms. The extremely yellow to orange coloration, or gold pattern as described, and the irregular black markings on body (which are not bilaterally symetrical, and with individual differences between the three specimens as stated in the original description) strongly suggest this. Like albino or melanin phenotypes, xanthochromism can be expressed partially or totally, and the specimen described by Knaack seems to represent a partial xanthic form.

Rineloricaria cacerensis is currently only known from the lectotype and two paralectotypes. This species is very similar to $R$. melini in the coloration pattern, and similar to other species as $R$. fallax, $R$. formosa, $R$. hasemani, $R$. jubata, $R$. melini, $R$. morrowi, and $R$. teffeana in the overall morphology. However, we can not be conclusive of his status without a taxonomic revision of the above cited Amazonian species, and this is outside the scope of this paper. We encourage further investigations on $R$. cacerensis with the inclusion of these similar forms, especially because the diagnostic differences mentioned here for this species are mainly coloration characters based only on its original description and examination of the three types, which are clearly juvenile specimens. We decided to maintain this species as valid and provide a tentative diagnosis, description, photographs, and measurements of the type specimens to help to define its taxonomic status. Noteworthy, despite the large amount of specimens analyzed from the Paraguay River basin during this revision we did not found more specimens of $R$. cacerensis beside the type series. This lack of material could be due to insufficient collecting efforts, a geographical distribution restricted merely to the upper portions of the Paraguay River near Cáceres, or a mistake when cataloging type locality; however, discarding any of these alternatives is difficult.

Rineloricaria hoehnei (Miranda Ribeiro, 1912) was described based on a single immature specimen of $46.8 \mathrm{~mm}$ SL collected in the city of Coxim (drainage of the rio Taquari, Paraguay River basin), Mato Grosso do Sul State, Brazil. This species is commonly cited in catalogs or manuals, but it is just known from its original description and holotype (Ferraris, 2003; Britski et al., 2007; Ghazzi \& Oyakawa, 2007). We analyzed the holotype (Fig. 10) and concluded that the color pattern of the fins, snout form, plate arrangements and counts correspond to typical characters of $R$. lanceolata. Indeed, we did not find any diagnostic differences between $R$. hoehnei specimens from the whole Paraguay River basin (usually identified as $R$. lanceolata) and several $R$. lanceolata specimens from the Amazonas River basin [including the río Marañón in Peru (type locality), as well as Madre de Dios, Guaporé, Ji-Paraná, Purus, and Solimões rivers] and the rio Araguaia basin by analyzing external morphology and osteological counts. Our analysis including the PCA detailed above evidenced that specimens from those basins exhibit similar morphometric values, color pattern, and shape of the snout and body (Table 1, Fig. 1a). Consequently, R. hoehnei is herein considered as a junior synonym of $R$. lanceolata because it is the older name available according to the Article 23 of the ICZN (1999). In this revision, we examined specimens from the Amazonas and Araguaia river basins corroborating the wide geographical distribution of $R$. lanceolata as previously described by Isbrücker (1973), and we expand the distribution range of this species to the Paraguay River basin.

Comparative material. Rineloricaria aequalicuspis Reis \& Cardoso, 2001: MCP 10794, 1, paratype, 144.3 mm SL, rio Maquiné, Maquiné, Rio Grande do Sul, Brazil. Rineloricaria altipinnis (Breder, 1925): AMNH 8404, photograph of holotype, $154.0 \mathrm{~mm}$ SL, río Chico, Darien, Panamá. Rineloricaria anhaguapitan Ghazzi, 2008: MCP 21074, 1, paratype, 119.7 mm SL, rio Passo Fundo, Entre Rios do Sul, Rio Grande do Sul, Brazil. Rineloricaria anitae Ghazzi, 2008: MCP 19685, holotype, 106.3 mm SL, rio Canoas, Campos Novos, Santa Catarina, Brazil. Rineloricaria baliola Rodriguez \& Reis, 2008: MCP 39922, holotype, 145.6 mm SL, rio Ingaí, Fortaleza dos Valos, Rio Grande do Sul, Brazil. Rineloricaria beni (Pearson, 1924): CAS 28772, holotype, 72.1 mm SL, lago Rogoagua (Beni River basin), Departamento del Beni, Bolivia. Bolivia: Cochabamba: UMSS 227, 9 of 10, 88.7-118.8 mm SL, río Raya, Chaparé. Rineloricaria cadeae (Hensel, 1868): Brazil: Rio Grande do Sul: MCP 19431, 12, 78.8-106.2 mm SL, rio Pardo, Candelaria. Rineloricaria capitonia Ghazzi, 2008: MCP 19687, holotype, 143.7 $\mathrm{mm}$ SL, rio Alegre, Condor, Rio Grande do Sul, Brazil. Rineloricaria caracasensis (Bleeker, 1862): RMNH 3120, photograph of holotype, 74.6 mm SL, Caracas, Venezuela. Rineloricaria castroi Isbrücker \& Nijssen, 1984: MZUSP 15731, holotype, 160.0 mm SL, rio Trombetas at Reserva Biológica do rio Trombetas, Estado do Pará, Brazil. Bolivia: Beni: UMSS 2775, 1, 130.0 mm SL, río Blanco, Todos Santos. Brazil: Amazonas: MCP 29749, 1, 74.5 mm SL, afluente do lago Mamirauá (Solimões River basin), Alvarães. MCP 29823, 1, 81.2 mm SL, rio Solimões, Alvarães. MCP 29832, 1, 76.7 mm SL, rio Tefé, Tefé. MCP 30626, 2, 127.4-168.3mm SL, rio Solimões, Alvarães. MCP 33249, 1, 121.9 mm SL, afluente do lago Mamirauá (Solimões River basin), Alvarães. MCP 33250, 1, 99.4 mm SL, afluente do lago Mamirauá (Solimões River basin), Alvarães. MCP 33251, 1, 130.0 mm SL, Paraná Maiana, Tefé. Pará: MCP 21016, 1, 134.4 mm SL, rio Amazonas, Ilha de São Miguel. Rineloricaria cf. catamarcensis (Berg, 1895): Bolivia: Tarija: ANSP 69309, 1, 70.1 mm SL, río Lipeo. Rineloricaria eigenmanni (Pellegrin, 1908): MNHN 1899-0118, lectotype, 127.0 mm SL, Sarare, Venezuela. Colombia: Meta: NRM 27775, 14, 78.3-120.5 mm SL, río Ocoa, Villa Vicencio. Venezuela: Portuguesa: UMMZ 214752, 1, 95.1 mm SL, arroyo Caramaguán, San Fernado de Apuré. Rineloricaria fallax (Steindachner, 1915): NMW 44864, photograph of lectotype, 147.7 mm SL, Igarapé de Carauná near Boa Vista, Roraima State, Brazil. ZSM 4869, photograph of paralectotype, $140.8 \mathrm{~mm}$ SL, same data as lectotype. Brazil: Roraima State: MCP 46206, 4, 122.8-158.0 mm SL, igarapé Jaburu entre Jundiá e Rorainópolis. Rineloricaria formosa Isbrücker \& Nijssen, 1979: FMNH 83713, photograph of holotype, 126.8 mm SL, río Inirídia, Puerto Inírida, Colombia. Brazil: Amazonas: MZUSP 6726, 8, 109.7-127.3 mm SL, rio Negro, Manaus. MZUSP 38969, 2, 69.8-80.1 mm SL, igarapé Acaraposo, São Gabriel da Cachoeira. MZUSP 88797, 2, 69.4-93.0 mm SL, rio Preto da Eva, rio Preto da Eva. Rineloricaria hasemani Isbrücker \& Nijssen, 
1979: NMW 44865, holotype, 145.7 mm SL, Maguary near Belém, Pará State, Brazil. Brazil: Pará State: MCP 22005, 1, 67.1 mm SL, igarapé Curupure, Acará. MCP 46007, 2, 53.0-56.8 mm SL, tributary of rio Acará, Acará. Rineloricaria heteroptera Isbrücker \& Nijssen, 1976: IRSNB 555, holotype, 120.4 mm SL, creek in reserve Ducke, near Manaus, Amazonas State, Brazil. MZUSP 38954, paratypes, 7, same data of holotype. Brazil: Amazonas State: MZUSP 81422, 6, 25.8-98.3 mm SL, igarapé Açaí, São Pedro. MZUSP 85177, 2, 34.5-82.9 mm SL, igarapé Onça, Assunção. MZUSP 88933, 5, 23.8-137.1 mm SL, rio Preto da Eva, rio Preto da Eva. Pará: MZUSP 52762, 2, 40.7-58.3 mm SL; MZUSP 53696, 2, 73.8-81.7 mm SL; igarapé Periquito, Porto Trombetas. Rineloricaria isaaci Rodriguez \& Miquelarena, 2008: MCP 9670, 1, paratype, 97.2 mm SL, Missões, Panambí, Condor, Rio Grande do Sul State, Brazil. Rineloricaria konopickyi (Steindachner, 1879): NMW 44934, holotype, dem mittleren Laufe des Amazonenstromes. Rineloricaria kronei (Miranda Ribeiro, 1911): Brazil: Paraná State: MCP 34592, 10, 78.6-144.0 mm SL, rio do Cerne, Campina Grande do Sul. Rineloricaria magdalenae (Steindachner, 1879): NMW 45080, photograph of lectotype, $129.1 \mathrm{~mm}$ SL, Magdalenen-Stromes, Colombia. Rineloricaria malabarbai Rodriguez \& Reis, 2008: MCP 39923, holotype, 82.5 mm SL, arroio Corupa, Agudo, Rio Grande do Sul State, Brazil. Rineloricaria maquinensis Reis \& Cardoso, 2001: MCP 25817, holotype, $81.3 \mathrm{~mm}$ SL, arroio Àgua Parada, Maquiné, Rio Grande do Sul State, Brazil. Rineloricaria melini (Schindler, 1959): NRM 25560, photograph of holotype, $130.0 \mathrm{~mm}$ SL, Manacapuru, Amazonas State, Brazil. Rineloricaria microlepidogaster (Regan, 1904): Brazil: Rio Grande do Sul State: MCP 34764, 137.4 mm SL, Ribeirão Asperezas, Pelotas. Rineloricaria misionera Rodríguez \& Miquelarena, 2005: MCP 35793, paratype, 3, 66.684.3 mm SL, arroyo Liso, Cainguás, Misiones, Argentina. Rineloricaria morrowi Fowler, 1940: ANSP 68663, photograph of holotype, Contamana, Peru. Brazil: Amazonas State: MZUSP 48798, 11, 27.8-125.5 mm SL, rio Uatumã, Presidente Figueiredo. Peru: Loreto: MCP 37160, 1, 95.1 mm SL, rio Nanay, Nauta. MCP 37162, 2, 167.0-175.0 mm SL, río Nanay, Loreto. MCP 43145, 3, 88.8-154.0 mm SL, Quebrada Correntillo, Iquitos. NRM 27838, 2, 92.0-130.1 mm SL, arroyo Sapuena, Colonia Angamos. Rineloricaria nigricauda (Regan, 1904): Brazil: Minas Gerais State: MCP 34224, 1, 89.6 mm SL, ribeirão Santana, Rio Preto. São Paulo State: MCP 20099, 3, 23.8-68.7 mm SL, rio Água Santa, São José do Barreiro. MCP 27451, 3, 97.2-102.2 mm SL, unspecified stream, Bananal. MCP 42379, 5, 28.6-90.3 mm SL, rio Piraitinga, Resende. MCP 45118, 2, 56.1-63.5 mm SL, córrego Convento, Pindamonhangaba. Rineloricaria osvaldoi Fichberg \& Chamon, 2008: Brazil: Goiás: MCP 15948, 8, 45.0-109.2 mm SL, córrego Fundo, Niquelândia. Rineloricaria phoxocephala (Eigenmann \& Eigenmann, 1889): MCZ 8030, photograph of lectotype, 150.0 mm SL, Coari, Brazil. $R$. cf. phoxocephala: Brazil: Amazonas State: MCP 29820, 1, 132.5 mm SL, tributary of lago Mamirauá, Alvarães. MCP 29829, 1, 107.1 mm SL, canal of lago Rato, Alvarães. MCP 29830, 1, 97.5 mm SL, tributary of Lago Mamirauá, Alvarães. MCP 29831, 1, 101.6 mm SL, rio Tefé, Tefé. Rineloricaria platyura (Müller \& Troschel, 1849): ZMB 3166, photograph of holotype, $125.0 \mathrm{~mm}$ SL, dem Rupununi, Guyana. FMNH 53080, photograph of holotype of Loricaria submarginatus Eigenmann, 1909, 57.0 mm SL, Creek below Potaro Landing, Guyana. Guyana: Essequibo: ANSP 177291, 1, 60.8 mm SL, río Siparuni. ANSP 182324, 1, 82.9 mm SL, río Siparuni. Rupununi: ANSP 182374, 1 of 2, 73.3 mm SL, río Simoni. ANSP 182376, 1 of 2, 59.9 mm SL, río Ireng . Rineloricaria cf. platyura:
Brazil: Pará State: MCP 22003, 2, 44.6-74.4 mm SL, tributary of rio Acará, Acará. MZUSP 23751, 5 of 10, 2, 72.3-84.6 mm SL (plus 3 ex. of R. formosa), Oriximiná. Rineloricaria quadrensis Reis, 1983: Brazil: Rio Grande do Sul State: MCP 9548, 4, 108.7127.8 mm SL, lagoa dos Quadros, Osório. Rineloricaria reisi Ghazzi, 2008: MCP 10851, paratype, 159.8 mm SL, rio Conceição, Augusto Pestana, Rio Grande do Sul State, Brazil. Rineloricaria rupestris (Schultz, 1944): USNM 121102, photograph of holotype, $79.0 \mathrm{~mm}$ SL, río San Pedro at bridge south of Mene Grande, Zulia State, Venezuela. Rineloricaria sanga Ghazzi, 2008: MCP 19686, holotype, 99.5 mm SL, Sanga das Águas Frias, Iraí, Rio Grande do Sul State, Brazil. Rineloricaria setepovos Ghazzi, 2008: MCP 19680, holotype, $106.0 \mathrm{~mm}$ SL, rio Piratini, Santo Ângelo, Rio Grande do Sul State, Brazil. Rineloricaria sneiderni (Fowler, 1944): ANSP 71433, photograph of holotype, 122.0 mm SL, río Jurubidá, Nuquí, in brook, Colombia. Rineloricaria steindachneri (Regan, 1904): NMW 45016, lectotype, from the rio Preto to the rio Paraíba, eastern Brazil. Rineloricaria stellata Ghazzi, 2008: MCP 19682, holotype, 90.0 mm SL, rio Ijuí, Ijuí, Rio Grande do Sul State, Brazil. Rineloricaria stewarti (Eigenmann, 1909): FMNH 53330, photograph of holotype, $64.0 \mathrm{~mm}$ SL, Chipoo Creek, a tributary of the Ireng, Guyana. MCZ 30058, photograph of paratype, $52.0 \mathrm{~mm}$ SL, Chipoo Creek, Guyana. French Guiana: Saint Laurent du Maroni: NRM 32369, 1, 73.8 mm SL, unspecified stream, Saut Sabbat. NRM 32379, 1, 85.4 mm SL, riviere Acarohuany, Cayenne. Guyana: Rupununi: ANSP 182361, 1, 68.4 mm SL, Moco-Moco River, Lethem. ANSP 182378, 1, 53.4 mm SL, Sauriwau River, Sand Creek. Siparuni: ANSP 175894, 4, 37.3-49.8 mm SL, creek along Kurupukari-Surama River road. ANSP 175895, 2, 50.5-57.4 mm SL, creek near Burro Burro campsite. Rineloricaria strigilata (Hensel, 1868): MCP 25450, 117.8 mm SL, lageado do Gringo, Agudo, Rio Grande do Sul State, Brazil. Rineloricaria teffeana (Steindachner, 1879): NMW 45134, lectotype, 123.4 mm SL, Amazon River near Tefé, Brazil. MCZ 8037, photograph of paralectotype, 125.0 mm SL, Amazon River near Tefé, Brazil. MNHN a-1985, photograph of holotype of Loricaria valenciennesi Vaillant, 1880, Calderon, Brazil. R. cf. teffeana: Brazil: Amazonas: MCP 29748, 1, 119.8 mm SL, lago Amanã (Solimões River basin), Maraã. MCP 29750, 1, 85.5 mm SL, lago Amanã (Solimões River basin), Maraã. MCP 36497, 4, 57.0-63.4 mm SL, rio Ipixuna, Humaita. MCP 36498, 1, 48.4 mm SL, rio Maicimirim, Humaitá. Rondônia State: MCP 36499, 2, 63.0-66.0 mm SL, affluent of rio das Garças, Porto Velho. MCP 36500, 1, 47.7 mm SL, igarapé bananeiras, Guajará-Mirim. MCP 36502, 2, 103.6-105.8 mm SL, affluent of rio Candéias, Ariquimes. MCP 46006, 1, 54.2 mm SL, igarapé bananeiras, Guajará-mirim. Rineloricaria thrissoceps (Fowler, 1943): Uruguay: Rocha: MCP 14068, 90.0 mm SL, Rocha. Rineloricaria tropeira Ghazzi, 2008: MCP 19684, holotype, 88.1 mm SL, arroio Passo do Carro, Vacaria, Rio Grande do Sul State, Brazil. Rineloricaria uracantha (Kner, 1863): USNM 16673, holotype of Loricaria bransfordi Gill, 1877, Isthmus of Panama, Empire Station. Rineloricaria wolfei Fowler, 1940: ANSP 68660, photograph of holotype, Ucayali River basin, Contamana, Peru. Brazil: Amazonas State: NRM 27835, 11, 19.1-163.2 mm SL (plus 1 ex. of Loricariichthys sp.), locality not specified. Peru: Loreto: MCP 28204, 3, 137.0-152.0 mm SL, río Itaya, Iquitos. MCP 43144, 4, 88.0-131.0 mm SL, río Itaya, Iquitos. NRM 27794, 3, 97.2-120.0 mm SL, arroyo Huayti, Gramalotales. NRM 27833, 4, 91.6-125.1 mm SL, arroyo Santa Helena, Loreto. NRM 27837, 9, 59.3-156.1 mm SL, río Galvez, Loreto. Rineloricaria zaina Ghazzi, 2008: MCP 19683, holotype, 118.4 mm SL, rio Buricá, Independência, Rio Grande do Sul State, Brazil. 


\section{Acknowledgements}

This study was part of the of the M.Sc. dissertation of the first author. HSVA is a PEC-PG student with grants from the CNPq (M.Sc. scholarship; process 19417/2006-4) and CAPES (Ph.D. scholarship). CNPq also provided grants to CSP and to CHZ. HSVA thanks M. Vera and T. Alcaraz for providing supports for visiting museums and collecting material; PEAUEM for providing support for visiting museums; A. Bifi, E. Pereira, F. Jerep, F. Lima, G. Solalinde, H. Júlio-Jr, I. Fichberg, L. Fulone, L. Ingenito, L. de Sousa, L. Villa-Verde, M. Ghazzi, M. Rodriguez, M. Sabaj, R. Covain, R. Ota, R. Reis, T. Carvalho, V. Sant'Anna, and W. da Graça for their help and discussions when elaborating the manuscript, providing photographs and literature, and assistance when visiting collections. We thank A. Ribeiro, D. Nelson, F. Bockmann, F. Carvajal, F. Langeani, F. de Souza, H. Ortega, L. R. Malabarba, M. Britto, M. Lucena, M. Sabaj, O. Froehlich, O. Oyakawa, O. Shibatta, P. Buckup, S. Kullander, and V. Abilhoa for loaning material. The authors were participants of the ACSI Project (All Catfish Species Inventory), financed by the National Science Foundation-USA, which afforded CHZ visiting several museums.

\section{Literature Cited}

Aquino, A. E. \& S. A. Schaefer. 2002. The temporal region of the cranium of loricarioid catfishes (Teleostei: Siluriformes): Morphological diversity and phylogenetic significance. Zoologischer Anzeiger, 241: 223-244.

Arratia, G. \& M. Gayet. 1995. Sensory canals and related bones of tertiary siluriform crania from Bolivia and North America and comparison with recent forms. Journal of Vertebrate Paleontology, 15: 482-505.

Bookstein, F. L. 1989. "Size and Shape”: A comment on semantics. Systematic Zoology, 38: 173-180.

Boulenger, G. A. 1895. Abstract of a report on a large collection of fishes formed by Dr. C. Ternetz in Matto Grosso and Paraguay, with descriptions of new species. Proceedings of the General Meetings for Scientific Business of the Zoological Society of London, 1895: 523-529.

Boulenger, G. A. 1896. On a collection of fishes from the Rio Paraguay. Transactions of the Zoological Society of London 14: 25-39.

Britski, H. A., K. Z. S. Silimon \& B. S. Lopes. 1999. Peixes do Pantanal: manual de identificação. Brasília, Embrapa-SPI, Corumbá, Embrapa-CPAP, 184p.

Britski, H. A., K. Z. S. Silimon \& B. S. Lopes. 2007. Peixes do Pantanal: manual de identificação. Brasília, DF, Embrapa, $2^{\text {nd }}$ Edition, 230p.

Carvalho, T. P. \& J. S. Albert. 2011. The Amazon-Paraguay divide. Pp: 193-202. In: Albert, J. S. \& R. E. Reis (Eds.). Historical Biogeography of Neotropical freshwater fishes. Berkeley, University of California Press, 388p.

Chernoff, B., D. Mandelburger, M. Medina, M. Toledo-Piza \& J. Sarmiento. 2001. List of fishes and the subregions where they were collected during the AquaRAP expedition to Departamento Alto Paraguay, Paraguay, in September 1997. Pp: 143-147. In: Chernoff, B., P. W. Willink \& J. R. Montambault (Eds.). A biological assessment of the aquatic ecosystems of the Río
Paraguay Basin, Alto Paraguay, Paraguay. Washington DC, Rap Bulletin of Biological Assessment nº19, 156p.

Covain, R. \& S. Fisch-Muller. 2007. The genera of the Neotropical catfish subfamily Loricariinae (Siluriformes: Loricariidae): a practical key and synopsis. Zootaxa, 1462: 1-40.

Eigenmann, C. H. 1909. The fresh-water fishes of Patagonia and an examination of the Archiplata-Archhelenis theory. Reports of the Princeton University expeditions to Patagonia 1896-1899, 3: 225-374.

Eigenmann, C. H. 1910. Catalogue of the fresh-water fishes of tropical and south temperate America. Reports of the Princeton University expeditions to Patagonia 1896-1899. Zoology Catalogue, 3: 375-511.

Eigenmann, C. H., W. L. McAtee \& D. P. Ward. 1907. On further collections of fishes from Paraguay. Annals of the Carnegie Museum, 4: 110-157.

Ferraris, C. J. Jr. 2003. Subfamily Loricariinae. Pp: 330-350. In: Reis, R. E., S. O. Kullander \& C. J. Ferraris (Eds.). Check list of the freshwater fishes of South and Central America. Porto Alegre, Edipucrs, 729p.

Ferraris, C. J. Jr. 2007. Checklist of catfishes, recent and fossil (Osteichthyes: Siluriformes), and catalogue of siluriform primary types. Zootaxa, 1418: 1-628.

Fichberg, I. \& C. C. Chamon, 2008. Rineloricaria osvaldoi (Siluriformes: Loricariidae): a new species of armored catfish from rio Vermelho, Araguaia basin, Brazil. Neotropical Ichthyology, 6: 347-354.

Fowler, H. W. 1932. Zoological results of the Matto Grosso Expedition to Brazil in 1931, I. Fresh water fishes. Proceedings of the Academy of Natural Sciences of Philadelphia, 84: 343-377.

Fowler, H. W. 1954. Os peixes de água doce do Brasil. Arquivos de Zoologia do Estado de São Paulo, 9: 1-400.

Ghazzi, M. S. 2008. Nove espécies novas do gênero Rineloricaria (Siluriformes, Loricariidae) do rio Uruguai, do sul do Brasil. Iheringia, Série Zoologia, 98: 100-122.

Ghazzi, M. S. \& O. T. Oyakawa. 2007. Família Loricariidae: Loricariinae. Pp: 87-91. In: Buckup, P. A., N. A. Menezes \& M. S. Ghazzi (Eds.). Catálogo das espécies de peixes de água doce do Brasil. Rio de Janeiro, Museu Nacional, 195p.

Günther, A. 1868a. Diagnoses of some new freshwater fishes from Surinam and Brazil, in the collection of the British Museum. Annals and Magazine of Natural History Ser. 4, 1: 475-481.

Günther, A. 1868b. Descriptions of freshwater fishes from Surinam and Brazil. Proceedings of the Zoological Society of London, 2: 229-247.

Hammer, O., D. A. T. Harper \& P. D. Ryan. 2001. PAST: Palaeontological Statistics Software Package for education and data analysis. Palaeontologia Electronica, 4: 1-9.

Heckman, C. W. 1998. The Pantanal of Poconé. Dordrecht, Kluwer Academic Publishers, 622p.

Ingenito, L. F. S., M. S. Ghazzi, L. F. Duboc \& V. Abilhoa, 2008. Two new species of Rineloricaria (Siluriformes: Loricariidae) from the rio Iguaçu basin, southern Brazil. Neotropical Ichthyology, 6: 355-366.

International Commission on Zoological Nomenclature. 1999. International code of zoological nomenclature, $4^{\text {th }}$ Edition. London, International Trust for Zoological Nomenclature 1999, 306p.

Isbrücker, I. J. H. 1973. Redescription and figures of the South American mailed catfish Rineloricaria lanceolata (Günther, 1868) (Pisces, Siluriformes, Loricariidae). Beaufortia, 278: 75-89.

Isbrücker, I. J. H. 1978. Descriptions préliminaries de nouveaux taxa de la famille des Loricariidae, poissons-chats cuirassés néotropicaux, 
avec un catalogue critique de la sous-famille nominale (Pisces, Siluriformes). Revue Française d'Aquariologie, 5: 86-117.

Isbrücker, I. J. H. 2001. Nomenklator der gattungen und arten der harnischwelse, Familie Loricariidae Rafinesque, 1815 (Teleostei, Ostariophysi). Datz Harnischwelse, 2: 25-32.

Isbrücker, I. J. H. \& H. Nijssen. 1976. Rineloricaria heteroptera, a new species of mailed catfish from Rio Amazonas near Manaus, Brazil (Pisces, Siluriformes, Loricariidae). Zoologischer Anzeiger, 196: 109-124.

Isbrücker, I. J. H. \& H. Nijssen. 1978. Two new species and a new genus of Neotropical mailed catfishes of the subfamily Loricariinae Swainson, 1838 (Pisces, Siluriformes, Loricariidae). Beaufortia, 27: 177-206.

Isbrücker, I. J. H. \& H. Nijssen. 1979. Three new South American mailed catfishes of the genera Rineloricaria and Loricariichthys (Pisces, Siluriformes, Loricariidae). Bijdragen tot de Dierkunde, 48: 191-211.

Isbrücker, I. J. H. \& H. Nijssen. 1992. Sexualdimorphismus bei Harnischwelsen (Loricariidae). Harnischwelse, 1992: 19-33.

Isbrücker, I. J. H., I. Seidel, J. P. Michels, E. Schraml \& A. Werner. 2001. Diagnose vierzehn neuer Gattungen der Familie Loricariidae Rafinesque, 1815 (Teleostei, Ostariophysi). DatzSonderheft Harnischwelse, 2: 17-24.

Jolicouer, P. \& J. E. Mosimann. 1960. Size and shape variation in the painted turtle. A principal component analysis. Growth, 24: 339-354.

Knaack, J. 2003. Ein neuer Prachthexenwels aus Paraguay: Hemiloricaria aurata n. sp. (Pisces, Siluriformes, Loricariidae). Aquaristik Aktuell, 11: 56-61.

Leviton, A. E., R. H. Gibbs Jr., E. Heal \& C. E. Dawson. 1985. Standards in Herpetology and Ichthyology: Part I. Standard symbolic for institutional resource collections in Herpetology and Ichthyology. Copeia, 1985: 802-832.

López, H. L., A. M. Miquelarena \& R. C. Menni. 2003. Lista comentada de los peces continentales de la Argentina. La Plata, Serie Técnica y Didáctica $N^{\circ} 5,85 p$.

Menni, R. C. 2004. Peces y ambientes en la Argentina continental. Buenos Aires, Monografias del Museo Argentino de Ciencias Naturales $N^{\circ}$ 5, 316p.

Miranda Ribeiro, A. de. 1911. Fauna brasiliense. Peixes. Tomo IV (A) [Eleutherobranchios Aspirophoros]. Archivos do Museu Nacional do Rio de Janeiro, 16: 1-504.

Miranda Ribeiro, A. de. 1912. História Natural. Zoologia. Loricariidae, Callichthyidae, Doradidae e Trichomycteridae. Commissão de Linhas Telegráphicas Estratégicas de MattoGrosso ao Amazonas, 5: 1-31.

Miranda Ribeiro, P. de. 1953. Tipos das espécies e subespécies do Prof. Alípio de Miranda Ribeiro depositados no Museu Nacional. Arquivos do Museu Nacional do Rio de Janeiro, 42: 389-417.

Morris, P. J., H. M. Yager \& M. H. Sabaj Pérez. 2006. ACSImagebase: A digital archive of catfish images compiled by participants in the All Catfish Species Inventory. Available from: http:// acsi.acnatsci.org/base (November 5, 2011)

Rapp Py-Daniel, L. H. \& I. Fichberg. 2008. A new species of Rineloricaria (Siluriformes: Loricariidae: Loricariinae) from rio Daraá, rio Negro basin, Amazon, Brazil. Neotropical Ichthyology, 6: 339-346.

Regan, C. T. 1904. A monograph of the fishes of the family Loricariidae. Transactions of the Zoological Society of London 17: 191-350
Ringuelet, R. A., R. A. Aramburu \& A. A. Aramburu. 1967. Los peces argentinos de agua dulce. Buenos Aires, Comisión de Investigación Científica, 602p.

Rodriguez, M. S. 2001. Dimorfismo sexual en Rineloricaria parva (Boulenger, 1895) (Pisces, Loricariinae). Natura Neotropicalis, 32: 169-172.

Rodriguez, M. S. 2003. Sistemática y distribución geográfica de peces de la familia Loricariidae (Ostariophysi: Siluriformes) de la Argentina con especial referencia a la tribu Loricariini. Unpublished Ph.D. Dissertation, Universidad Nacional de La Plata, La Plata. 284p.

Rodriguez, M. S. \& A. M. Miquelarena. 2002. On the southern distribution of Hemiloricaria lanceolata (Günther, 1868) (Loricariidae: Loricariinae). Biogeographica, 78: 159-164.

Rodriguez, M. S. \& A. M. Miquelarena, 2008. Rineloricaria isaaci (Loricariidae: Loricariinae), a new species of loricariid fish from the Uruguay River basin. Journal of Fish Biology, 73:1635-1647.

Rodriguez, M. S. \& R. E. Reis. 2008. Taxonomic review of Rineloricaria (Loricariidae: Loricariinae) from the Laguna dos Patos drainage, Southern Brazil, with the descriptions of two new species and the proposition of two species groups. Copeia, 2008: 333-349.

Schaefer, S. A. 1997. The neotropical cascudinhos: systematics and biogeography of the Otocinclus catfishes (Siluriformes: Loricariidae). Proceedings of the Academy of Natural Sciences of Philadelphia, 148: 1-120.

Steindachner, F. 1915. Beiträge zur Kenntniss der Flussfische Südamerikas V. Denkschriften der MathematischNaturwissenschaftlichen Classe der Kaiserlichen Akademie der Wissenschaften in Wien, 93: 15-106.

Taylor, W. R. \& G. C. van Dyke. 1985. Revised procedures for staining and clearing small fishes and other vertebrates for bone and cartilage study. Cybium, 9: 107-119.

Vera A., H. S. \& H. del Castillo. 2006. Capitulo 4. Peces del Río Paraguay. Pp: 40-58. In: Morales, C., A. Yanoski, L. Luna, E. Cabrera \& S. Centrón (Eds.). Biodoversidad del Río Paraguay. Asunción, Guyra Paraguay-Transbarge Navegation, 122p.

Submitted April 19, 2010

Resubmitted November 20, 2011

Accepted March 21, 2012

Published June 29, 2012 